\title{
Experimental Testing of a Low-Damage Post-Tensioned C-shaped CLT Core-Wall
}

\author{
Justin Brown ${ }^{1}$, Minghao $\mathrm{Li}^{2}$, Alessandro Palermo ${ }^{2}$, Stefano Pampanin ${ }^{3}$, and Francesco Sarti ${ }^{4}$ \\ ${ }^{1}$ Department of Civil and Natural Resources Engineering, University of Canterbury, New Zealand. \\ Email: justin.brown@pg.canterbury.ac.nz \\ ${ }^{2}$ Department of Civil and Natural Resources Engineering, University of Canterbury, New Zealand. \\ ${ }^{3}$ Department of Structural and Geotechnical Engineering, Sapienza University of Rome, Italy \\ ${ }^{4}$ PTL | Structural Consultants, Christchurch, New Zealand
}

\begin{abstract}
The development of strong and stiff lateral load resisting systems (LLRS) is essential for mid-rise and high-rise timber buildings. On the other hand, within a seismic design philosophy strength/stiffness and ductility/drift capacity typically appear as opposite target parameters, depending on the acceptable level of damage. For improved stiffness and strength, core-wall tubular structural forms are commonly used for taller reinforced concrete buildings. This paper presents an experimental study on a new type of LLRS in cross-laminated timber (CLT). A post-tensioned C-shaped CLT core-wall mainly using screwed connections was designed and tested under uni-directional and bi-directional cyclic loading. It was found that the mixed angle screwed connection solution was the most effective. The highest partial composite action of $60-70 \%$ was reached and the core-wall system stiffness at serviceability limit state increased more than four times when compared to a decoupled test with only friction between the CLT panels. The (unbonded) post-tensioning technology provided strong and stiff core-wall base connections with re-centering capability and small residual displacements. The experimental test results confirmed that significant system strength/ stiffness and ductility/drift capacity can be achieved in a post-tensioned C-shaped CLT core-wall system with minimal damage through careful connection detailing.

\section{INTRODUCTION}

Timber is experiencing a renaissance as a building material. Engineered wood products such as cross- 
laminated timber (CLT) are being produced to a high degree of prefabrication which allows for efficient and safe on-site installation. CLT has been applied globally in many low-rise and mid-rise buildings typically following the platform construction technology (Green and Taggart 2017). Under seismic loads, conventional CLT shear walls with properly designed connection systems are able to provide adequate lateral capacity for multi-storey buildings. However, in the cases of open commercial floor plans or taller buildings, conventional CLT shear walls may struggle to achieve the required strength and stiffness performance with current design methodologies. One possible improvement is to adopt hybrid systems with steel or concrete. Another possible solution is to introduce flanged core-walls that can develop composite action among in-plane and orthogonal walls to enhance lateral strength and stiffness. While the flanged core-wall concept is common for reinforced concrete structures (Khan and Sbarounis 1964; Beyer et al. 2008), few studies for mass timber core-wall buildings were reported. One rare recent example of mass timber core-walls is the Catalyst building (2018) in Spokane, WA which required performance based engineering for code compliance through project specific testing (McDonnell and Jones 2020). However, in general the lack of design guides and the challenge of forming robust connections between orthogonal walls to achieve composite action are hindrances to further application of this system type.

Conventional CLT shear walls have been researched widely in the last two decades (Pei et al. 2016). Dujic et al. (2004) were the first to test in-plane CLT walls. Since then, in-plane CLT shear walls have been extensively researched with standard connection systems (Popovski et al. 2010; Gavric et al. 2015; Flatscher et al. 2015; Hummel 2016; Amini et al. 2018). These standard connectors include commercially available hold-downs and shear brackets which are connected to CLT wall panels mainly with nails and screws. Research has reported that CLT wall panels behave relatively rigid in low- to medium-rise buildings and that the connections are critical and govern the wall behaviour, typically limiting their ductility/drift capacity (Izzi et al. 2018). More recently, seismic performance factors for platform framed CLT shear walls systems in the United States were determined by van de Lindt et al. (2020) following the FEMA P695 (FEMA 2009) methodology for inclusion in the 2021 AWC Special Design Provisions for Wind \& Seismic. In CLT platform construction, connections with self-tapping screws (STS) are commonly used. This is increasingly the case for vertical joints between CLT wall panels with recent aspect ratio (height-to-length) limitations between 1:1 and 4:1 (Tannert 2019; CSA 086 2019). This coupling effect will provide increased system displacement capacity and energy dissipation. Experimental testing on STS connections has shown that inclined screws are able to provide higher stiffness and strength but lower ductility when compared with screws installed at $90^{\circ}$ to the timber surface (or simply called $90^{\circ}$ screws). However, by using screws installed with mixed angles, stiff and ductile STS connection performance can be achieved for both in-plane and orthogonal CLT panel joints 
(Hossain et al. 2016; Sullivan et al. 2018). Due to the limited stiffness and strength of conventional CLT shear wall systems with commercially available hold-downs and shear brackets, their implementation has been generally limited to low-rise or mid-rise residential buildings. For taller timber buildings or timber buildings with a limited amount of walls, Buchanan (2016) stated that transforming conventional shear walls to core-wall systems and also by using efficient connection systems such as post-tensioning for connections between timber elements or timber elements and foundations could meet the increased stiffness and strength demands.

Adapting concepts and principles originally developed for precast concrete construction (Priestley et al. 1999), post-tensioned timber systems, also called Pres-Lam technology (Prestressed Laminated Timber), have been developed and tested since 2005 at the University of Canterbury (UC) (Palermo et al. 2005). In post-tensioned timber shear walls, conventional hold-downs are not used and the moment capacity at the wall base is provided by the clamping action of the post-tensioned tendons and/or by special ductile "hold-downs", consisting of axially loaded internally epoxied or external and replaceable rebars/dissipaters (Palermo et al. 2006). This system can maximize the stiffness achievable in mass timber structures, minimize damage, and have strong re-centering capabilities. An extensive testing programme at UC included post-tensioned laminated veneer lumber (LVL) single wall testing (Palermo et al. 2005; Palermo et al. 2006), hybrid wall systems with internal epoxied and external replaceable energy dissipating devices (Sarti et al. 2016), U-shaped flexural plates in coupled walls (Iqbal et al. 2015a; Kelly et al. 1972), or simply coupled walls with nailed plywood sheets (Iqbal et al. 2015b). The importance of connection detailing between the diaphragm and the lateral load resisting system was highlighted during a two-storey frame and wall building experimental test by Newcombe et al. (2010a) and in-plane experimental testing of Timber-Concrete-Composite diaphragms (Newcombe et al. 2010b). This was subsequently extensively researched by Moroder et al. (2017). Careful detailing is required to resolve the wall-floor displacement incompatibilities. While initial research with post-tensioned mass timber systems focussed on using LVL for its inherent higher mechanical properties, recent notable work has also confirmed its usability with other engineered wood products such as Glulam (Smith et al. 2014; Di Cesare et al. 2017; Mancini and Pampanin 2018) and CLT (Dunbar et al. 2014; Ganey et al. 2017; Ho et al. 2017; Pilon et al. 2019; Chen et al. 2020). Under the multiyear Natural Hazards Engineering Research Infrastructure (NHERI) research project (Pei et al. 2017), Ganey et al. (2017) tested configurations of single and coupled post-tensioned CLT walls on both steel and CLT bases. In 2017, Pei et al. (2019b) conducted a series of shake table tests of a full-scale 2-storey mass timber building with post-tensioned CLT walls. At the end of the NHERI project, a ten-storey full scale post-tensioned CLT wall building shake table test is planned (Pei et al. 2019a). A current state-of-the-art in Pres-Lam concept, testing and implementation is provided by 
Granello et al. (2020). In past post-tensioned coupled wall tests, the primary purpose of the in-plane vertical joint between adjacent panel walls was to provide increased energy dissipation during the rocking motion (Iqbal et al. 2015a; Ganey et al. 2017; Chen et al. 2020). There are few examples using the in-plane vertical joint or orthogonal vertical joint as a method to provide increased strength and stiffness through partial composite action between the panels to create a C-, I-, or tube-shaped lateral load resisting system (LLRS), but this method could meet increased lateral stiffness demands for taller timber buildings. Cast in-situ reinforced concrete (RC) core-walls are popular for commercial construction. Corewall structures provide advantages architecturally by allowing for open floor plans, and structurally by developing a tube-like behaviour with high lateral stiffness and strength. Core-wall structures can also provide torsional stiffness which is important for centrally located LLRS on floor plans. The US ACI31811 (ACI 2011) provides design indications for a RC core-wall section to consider an effective flange width depending on the flange to web wall length ratio and total wall height and plastic hinging at the foundation level. A summary of experimental works on various flanged-type $\mathrm{RC}$ walls by Constantin and Beyer (2014) highlighted the complex behaviour of flanged walls and the importance of understanding bi-directional loading (Beyer et al. 2008). In Australia and New Zealand (NZ) precast concrete corewalls are also used and recent precast concrete core-wall experimental work by Menegon et al. (2020a) suggested that typical connections used between precast concrete panels are too flexible, and that typical grout tube connections to the foundation can result in unintended stress / strain concentrations. Thus, only partial composite core-wall behaviour is developed and ductility is limited. More robust connections with enhanced strength and stiffness for precast concrete core-walls were subsequently developed and tested to provide increased composite action (Menegon et al. 2020b). Mass timber core-wall construction is more similar to precast concrete construction in that connections are required to connect prefabricated panels together and also to the foundation. In contrast to a cast in-situ RC core-wall, a post-tensioned mass timber core-wall base connection stiffness is controlled by the stiffness of the post-tensioning elements and any supplementary energy dissipation devices. Two post-tensioned CLT stair-case core-walls with box configuration have been experimentally tested by Dunbar et al. (2014) with a small number of $90^{\circ}$ screws to connect the CLT panels together. While this work verified the feasibility of post-tensioned timber core-walls, there is a lack of comprehensive research work to quantify the increase in stiffness and strength achievable when considering the composite action of orthogonal walls. By engaging the post-tensioning elements of the flange walls, a post-tensioned timber core-wall base connection stiffness can be increased when compared to rectangular post-tensioned timber walls. Similar to precast concrete construction, mass timber core-wall structures require robust high-strength and high-stiffness connections to maximise composite action. 
This study aimed at evaluating the seismic performance of a post-tensioned flanged C-shaped CLT core-wall which can be designed as a LLRS in multi-storey mass timber buildings. As part of the experimental campaign, a total of seven different core-wall configurations were tested under uni-directional and/or bi-directional loading. Different STS connection methodologies were used to connect the CLT wall panels at the in-plane and orthogonal joints. Most of the solutions are also a valid cost-effective alternative to CLT platform construction in non-seismic areas. The construction detailing of the posttensioned core-wall specimen is presented first. The testing methodology is then introduced and the experimental results are discussed with a focus on the global post-tensioned core-wall behaviour and the local STS connection performance.

\section{TEST SPECIMEN DETAILING}

The complete experimental programme is introduced in Brown et al. (2020) which consisted of testing three post-tensioned CLT shear wall specimens: a single wall (SW) in test Phase I, a coupled double wall (DW) in test Phase II, and a flanged C-shaped core-wall (CW) in test Phase III. This paper presents the experimental testing of Phase III. In Phase III, various STS connection design options were used to investigate the influence of connection details on the composite shear wall actions and overall shear wall behaviour. The post-tensioned core-wall specimen was designed in accordance with the Pres-Lam design guide, with extensions made for post-tensioned core-wall design (Pampanin et al. 2013). Fig. 1 shows an isometric of the core-wall test set-up with key information.

\section{Wall Section Design}

The wall specimens were four-storey high with a $2 / 3$ scale factor. The CLT wall panels were five-ply and 175mm thick (45/20/45/20/45), with SG8 grade Douglas-fir laminations as specified in NZS3603 (Standards New Zealand 1993). To accommodate internal post-tensioning bars, 100mm x 45mm ducts were maintained in the middle layer of the CLT wall panels (refer to Fig. 1(a)).

All the wall components were designed to be assembled with a $2 \mathrm{~mm}$ tolerance. Fig. 1(a) shows the orientation of the four panels with respect to each other and location of the post-tensioning bars. Web walls 1 and 2 were $1912 \mathrm{~mm}$ in length and flange walls 3 and 4 were $1450 \mathrm{~mm}$ in length. Table 1 lists the mechanical properties of the CLT, post-tensioning bars and steel dissipaters. The flange walls were overlapped with the webs walls such that contact bearing would occur at the orthogonal joint during strong axis loading. A butt joint was chosen for the in-plane connection. Each wall had a horizontal joint at $5.5 \mathrm{~m}$ height which will be discussed further in castellation design.

\section{Connection Design}

\section{Screwed Connections}


Table 1. Material Properties

\begin{tabular}{llll}
\hline Material & Property & Symbol & Value \\
\hline Cross-laminated Timber & Modulus of Elasticity & $E_{0, \text { mean }}$ & $8000 \mathrm{MPa}$ \\
& Characteristic Compression Strength Parallel to Grain & $f_{c, 0}$ & $18 \mathrm{MPa}$ \\
& Characteristic Compression Strength Perpendicular to Grain & $f_{c, 90}$ & $8.9 \mathrm{MPa}$ \\
Post-tensioning Steel & $E_{p}$ & $170 \mathrm{GPa}$ \\
& Modulus of Elasticity & $f_{p y}$ & $835 \mathrm{MPa}$ \\
& Yield Stress & $f_{p u}$ & $1030 \mathrm{MPa}$ \\
& Ultimate Stress & $E_{s}$ & $200 \mathrm{GPa}$ \\
Mild Steel (Flat Bar) & Modulus of Elasticity & $E_{s y}$ & $300 \mathrm{MPa}$ \\
& Yield Stress & &
\end{tabular}

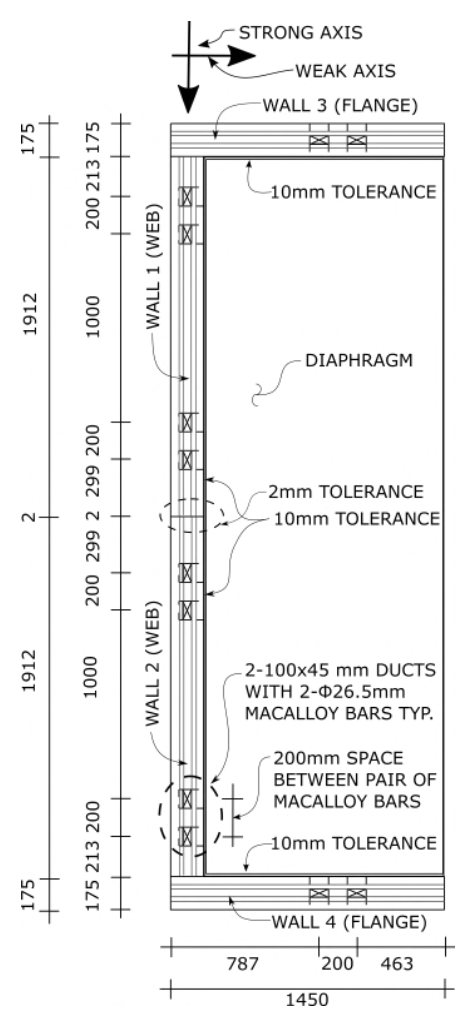

(a) Plan View: Core-Wall Arrangement

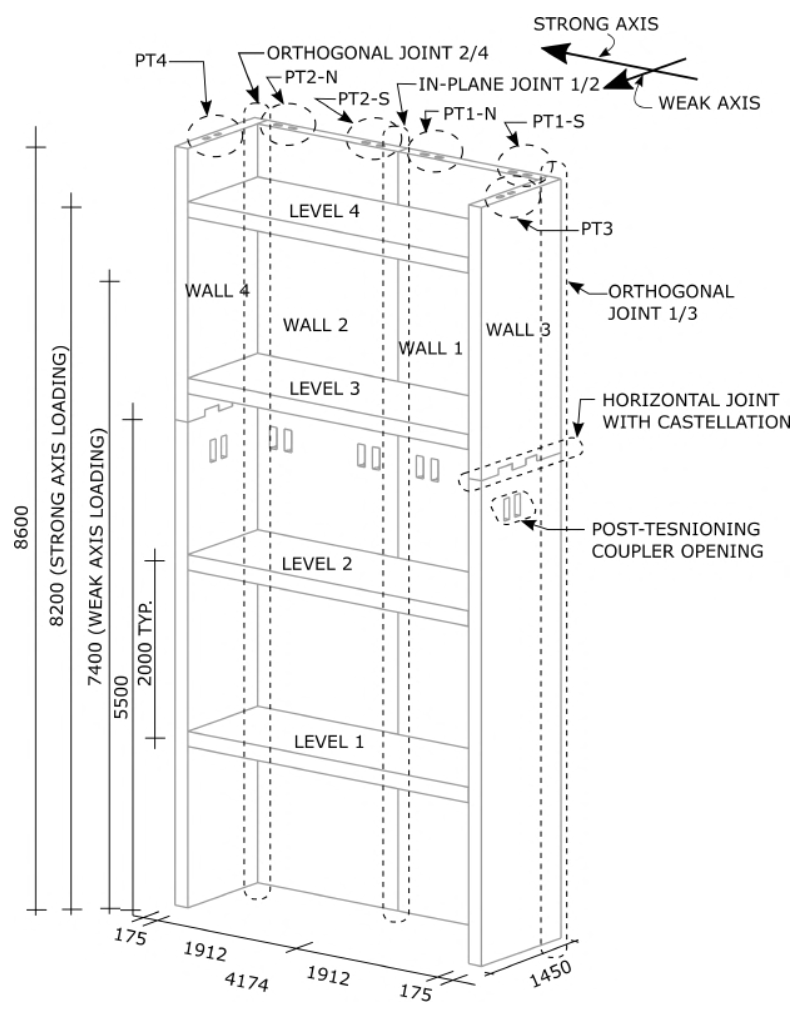

(b) Core-wall Test Isometric

Fig. 1. Core-wall Experimental Design

The in-plane and orthogonal joints of the core-wall adopted STS. The screws were installed at $90^{\circ}$, inclined, or mixed inclinations which can provide different connection strength, stiffness and displacement capacity. The different screw installations for the in-plane and orthogonal joint are shown in Fig. 2. The screwed connection design summary yield strength $\left(F_{y}\right)$ and stiffness $\left(K_{s e r}\right)$ predictions are provided in Table 2. The contribution from friction was neglected. For the in-plane joint, partially threaded (PT) or fully threaded (FT) screws were installed either at $90^{\circ}$ with plywood or at a $45^{\circ}+45^{\circ}$ double inclination. For the orthogonal joint, FT screws were installed either at $90^{\circ}$ or at a $60^{\circ}+15^{\circ}$ double inclination. 
Table 2. Screwed Connection Design Summary

\begin{tabular}{c|cc|cc|ccc}
\hline Test & \multicolumn{2}{|c}{ CW-2 \& CW-7 } & \multicolumn{2}{c}{ CW-5 } & \multicolumn{3}{c}{ CW-6 } \\
Orthogonal \\
Joint & In-Plane & Orthogonal & In-Plane & Orthogonal & In-Plane & Wall 1/3 Joint & Wall 2/4 Joint \\
\hline$F_{y}(\mathrm{kN} / \mathrm{m})$ & 36 & 30 & 60 & 84 & 150 & 68 & 63 \\
$K_{\text {ser }}(\mathrm{kNN} / \mathrm{mm} / \mathrm{m})$ & 18 & 23 & 45 & 67 & 121 & 55 & 51 \\
\hline
\end{tabular}

$F_{y}$ - yield strength prediction per metre of wall where shear-tension and shear-compression screws were determined as per Loss et al. (2018) and SPAX ETA (2017), and 90 screws were considered as per Eurocode 5 (2014) and SPAX ETA (2017)

$K_{s e r}$ - stiffness prediction per metre of wall which was considered for tension screws and was as per Loss et al. (2018) and SPAX ETA (2017)

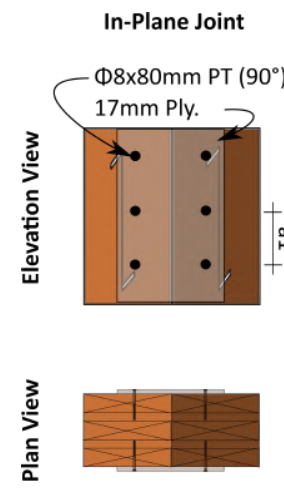

(a) Tests CW-2 and CW-7
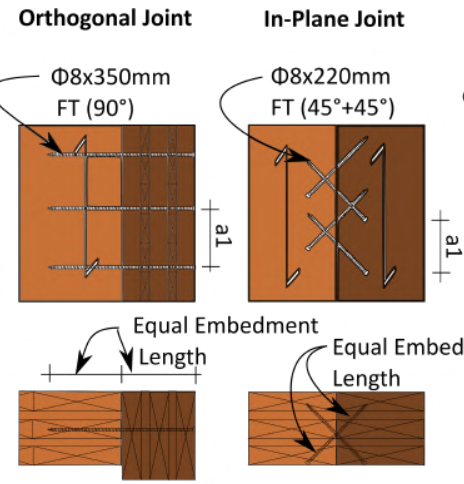

(b) Test CW-5
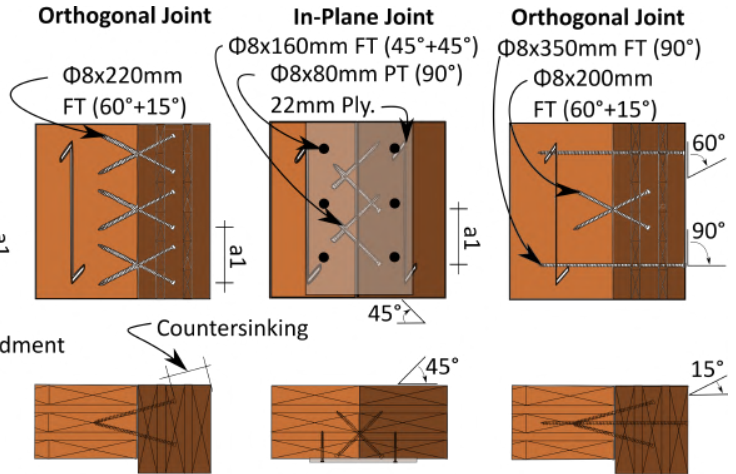

(c) Test CW-6

Fig. 2. Screw Connection Detailing

All inclined STS were installed with the minimum spacing $\left(a_{1}=10 d\right)$ according to Eurocode 5 (2014) and European Technical Approval (ETA 2017). There was equal screw threaded length on each side of the timber joint, which meant that countersinking was required on the orthogonal joint. In addition to providing system stiffness through composite action, the STS can provide a source of energy dissipation under large wall deformations (Popovski et al. 2010; Lauriola and Sandhaas 2006). 


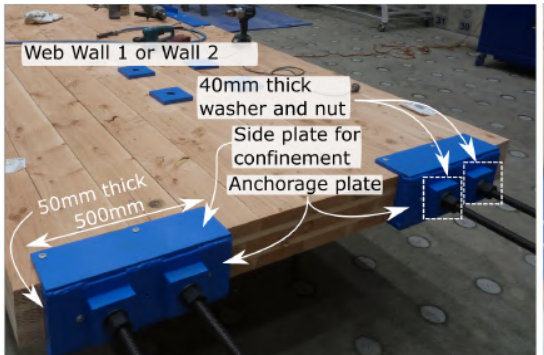

(a) Anchorage at Top of CLT Wall

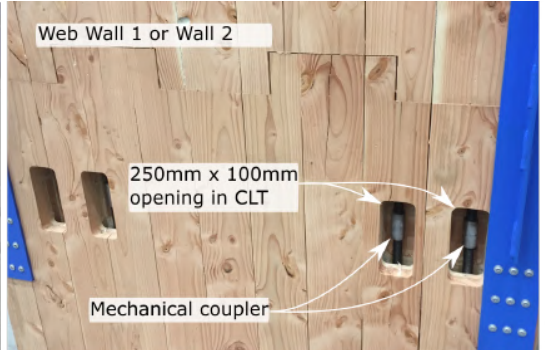

(b) Mechanical Coupler Location

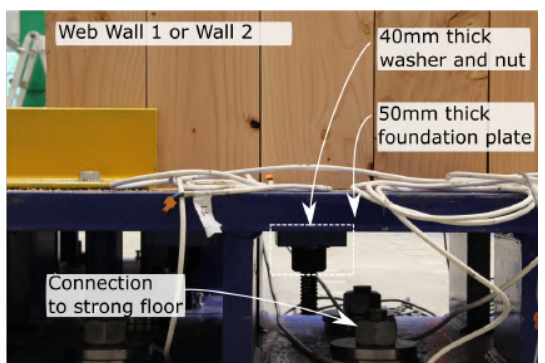

(c) Anchorage to Steel Foundation

Fig. 3. Post-tesnioning Anchorage Details

\section{Castellation Design}

Each CLT wall panel had a horizontal castellated joint located at a wall height of $5.5 \mathrm{~m}$ to transfer horizontal shear load. The purpose of the horizontal joint was to evaluate the effectiveness of such joints transferring high shear loads. The castellation height location was chosen to ensure sufficient diaphragm restraint and the two diaphragms above the castellation provided out-of-plane restraint. The castellation only provided in-plane restraint. Further, the castellation height was high enough to ensure that gap opening would not occur as the moment due to the applied lateral force was sufficiently smaller than the pre-compression due to the post-tensioning. Though high friction could be expected due to the clamping effect caused by high post-tensioning forces, Appendix B of NZS3101 (2006) (NZ Concrete Standard covering jointed ductile connections for precast concrete) does not allow shear resistance to be taken fully by friction. Thus, the castellated joint was conservatively designed to resist all the horizontal shear load. The castellation was fabricated by a computer numerical control (CNC) machine with $2 \mathrm{~mm}$ tolerance. Each wall had two castellations with an approximate 3:1 length to height ratio. The web wall castellations were $350 \mathrm{~mm}$ long and $120 \mathrm{~mm}$ high and the flange wall ones were $200 \mathrm{~mm}$ or $250 \mathrm{~mm}$ long and $70 \mathrm{~mm}$ high. A web wall castellation is shown in Fig. 4(a).

\section{Diaphragm Design}

CLT floor diaphragms provided out-of-plane restraint to the vertical wall components. Floors are generally constructed outside a core-wall system such that lift/elevator shafts, service shafts, or stairwells can be placed inside. However, in this study, by placing the diaphragms inside the core-wall, a selfcontained test specimen with its own out-of-plane restraints in bi-directional loading was achieved without the necessity of additional structural members. The floors had a 10mm gap from the walls with 
the intention to eliminate the strut action potential which was observed by Newcombe et al. (2010a). The floors were connected to each wall with a 700mm long Equal Angle (EA) $100 \mathrm{~mm} \times 100 \mathrm{~mm} \times$ 6mm (Australian / New Zealand Standard 2016) with predrilled $\phi 11 \mathrm{~mm}$ holes on the horizontal leg, and $11 \mathrm{~mm}$ x 20mm slotted holes on the vertical leg. A similiar detail had previously been tested by Moroder et al. (2017). Following the NZ Steel Structure Standard (NZS3404 (1992)), the design out-of-plane force of $2.5 \%$ axial load required $16-\phi 10 \times 100 \mathrm{~mm}$ partially threaded washer head screws with pre-drilled holes. This out-of-plane force demand was appropriate based on results from Phase I and II testing. The screws on the vertical leg were unscrewed a 1/4 turn after installation to accommodate global wall-floor displacement incompatibility through movement within the slotted hole connection. The steel angles were placed in the mid-length of each wall to minimize the displacement incompatibility as recommended by Moroder et al. (2018). A slotted hole diaphragm connection detail was also used in the NMIT building, which was the first post-tensioned timber building erected in 2011 (Holden et al. 2016). The diaphragm connection design is shown in Fig. 4(b).

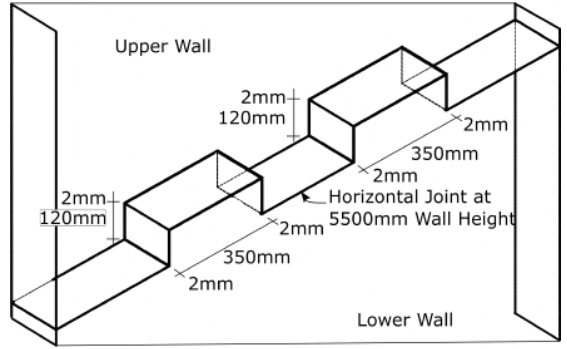

(a) Castellation Isometric

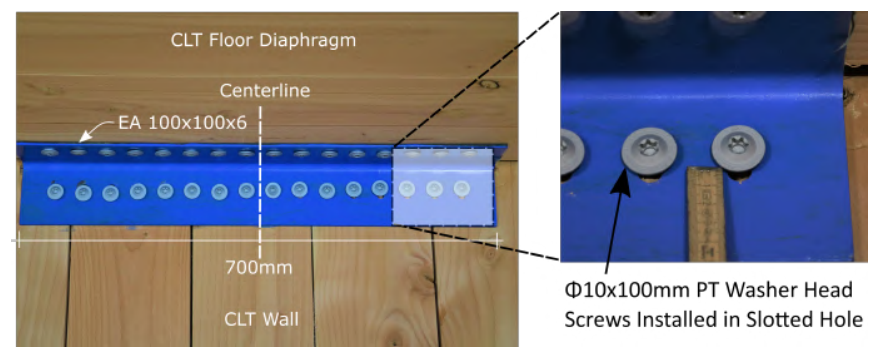

(b) Diaphragm Connection

Fig. 4. Connection Design

\section{Dissipater Design}

At the corners of each wall base, mild steel U-shaped flexural plates (UFPs) (Kelly et al. 1972) were installed. While past research (Iqbal et al. 2015a; Ganey et al. 2017; Pei et al. 2019b) and the NMIT building (Holden et al. 2016) have used UFPs between post-tensioned walls to provide coupling effect and stable energy dissipation, in this study the primary focus was to investigate different connection details of the UFPs to CLT wall panels. Implications due to bi-directional loading would be investigated as well. Sarti et al. (2016) have shown the importance of providing a stiff connection to engage the dissipaters. As such, three different connections were investigated which are shown in Fig. 5: (1) inclined screws installed in the face of CLT, (2) inclined screws installed in the edge of CLT, and (3) an epoxied plate on the face of CLT. Each inclined screw connection was designed to remain elastic with an overstrength factor of 1.8 neglecting friction and the contribution from screws under compression. Each UFP was 


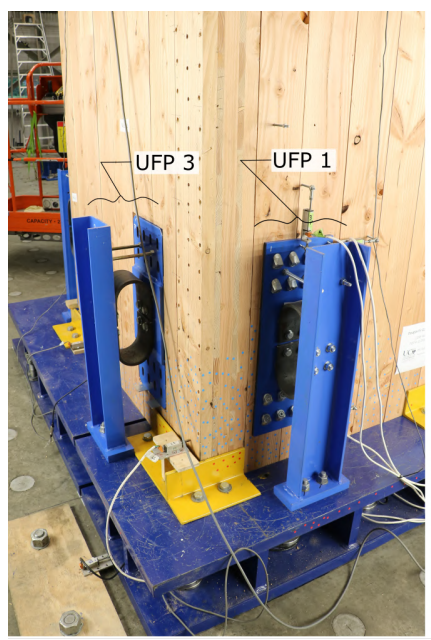

(a) UFP 3 (CLT Face, Epoxy) UFP 1 (CLT Face, Inclined Screwed)

connected by 2-M16 bolts to the steel plate and to the steel parallel flanged channel (PFC). $2-\phi 12 \mathrm{~mm}$

Grade 4.6 threaded rods (Standards New Zealand 1992) were installed to connect the PFC and the steel plate to eliminate the induced force couple because UFPs were placed only on one side of the CLT wall.

Tests with and without the $\phi 12 \mathrm{~mm}$ threaded rod were implemented.

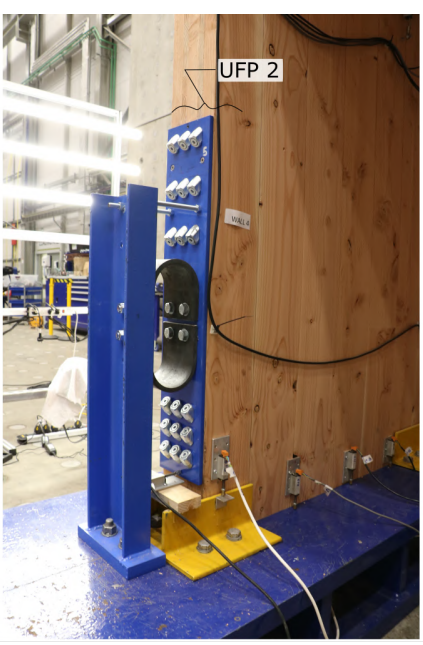

(b) UFP 2 (CLT Edge, Inclined Screwed)

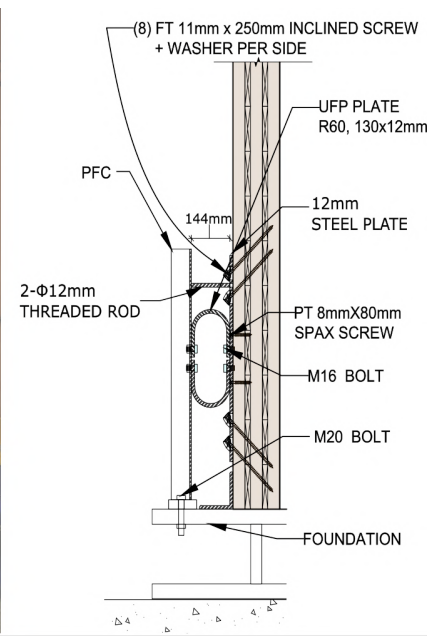

(c) UFP Typical Details

Fig. 5. UFP Connection Detailing

\section{Foundation Details}

Typically in post-tensioned timber buildings, large concrete pad foundations are used to transfer the concentrated loads from the post-tensioning bars while anchored steel plates can be used to transfer shear forces (Palermo et al. 2012). In this instance, a custom fabricated steel foundation provided connection to the strong floor, anchorage to the post-tensioning bars and a shear key connection. Shear keys were installed to prevent both in-plane and out-of-plane movement. The shear keys were EA $125 \mathrm{~mm}$ x $125 \mathrm{~mm}$ x 12mm (Australian / New Zealand Standard 2016) with welds on the bottom leg only so that the top leg could yield and bend to accommodate rocking as reported by Moroder et al. (2018) and also detailed for the Carterton Events Centre building (Palermo et al. 2012). The various shear keys used are shown in Fig. 6. The shear keys were bolted to the top flange of the steel foundation with Grade 8.8 M20 bolts (Standards New Zealand 1992) with zero tolerance. However, because the actual CLT web lengths and flange wall thicknesses were closer to $1910 \mathrm{~mm}$ and $173 \mathrm{~mm}$ respectively, approximately $8 \mathrm{~mm}$ tolerance occurred at the core-wall base during the strong axis loading.

\section{TEST PROGRAMME AND LOADING PROTOCOL}

The core-wall testing schedule is provided in Table 3. The tests considered variations in terms of a) initial post-tensioning force, b) screwed connection detail, c) use of UFPs, and d) loading protocols. The 

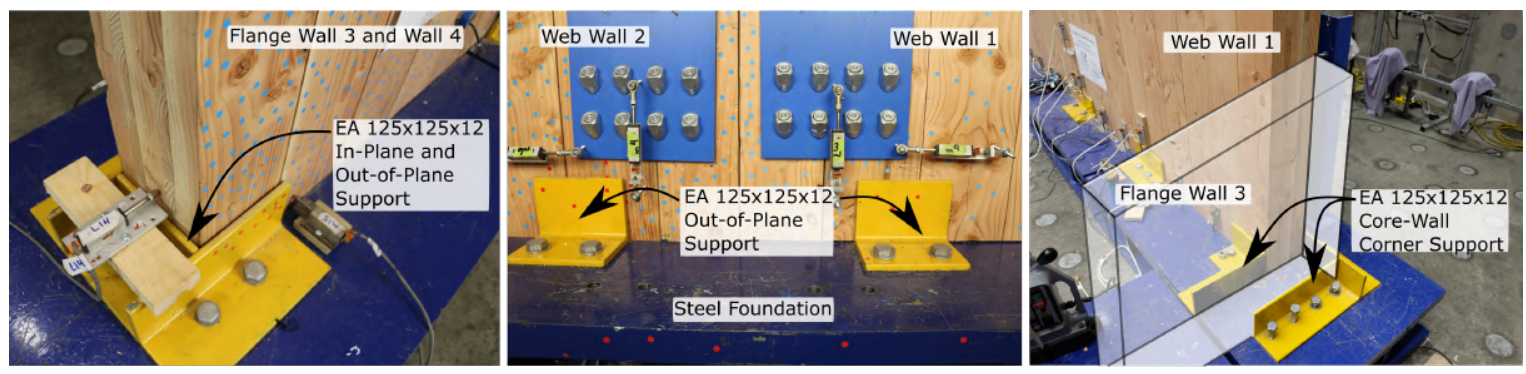

Fig. 6. Core-wall Shear Key Details to Foundation

initial post-tensioning force, differing from traditional unbonded post-tensioned concrete applications, is limited to $16 \%$ to avoid potential yielding due to wall uplifting. Fig. 2 has provided the details on each screwed connection type for the in-plane and orthogonal joints. Tests CW-1, 3 and 4 did not use STS at the wall joints such that friction between the panels could be quantified. This also provided a baseline and lower bound performance. The experimental test setup for the core-wall is shown in Fig. 7.

Table 3. Experimental Core-wall Test Programme

\begin{tabular}{|c|c|c|c|c|c|c|c|}
\hline \multirow[b]{2}{*}{ Test } & \multirow{2}{*}{$\begin{array}{c}\text { Initial Post- } \\
\text { Tensioning } \\
\text { per bar }(\mathbf{k N})\end{array}$} & \multicolumn{2}{|c|}{ In-Plane Joint } & \multicolumn{3}{|c|}{ Orthogonal Joint } & \multirow[b]{2}{*}{ UFP } \\
\hline & & Screw & $\begin{array}{l}\text { Screw Quantity } \\
\text { Wall } 1 / 2 \text { Joint }\end{array}$ & Screw & $\begin{array}{c}\text { Screw Quantity } \\
\text { Wall 1/3 Joint }\end{array}$ & $\begin{array}{l}\text { Screw Quantity } \\
\text { Wall 2/4 Joint }\end{array}$ & \\
\hline CW-1 & $25(5 \%) * *$ & Friction & $\mathrm{n} / \mathrm{a}$ & Friction & $\mathrm{n} / \mathrm{a}$ & $\mathrm{n} / \mathrm{a}$ & No \\
\hline CW-2 & $75(16 \%)^{* *}$ & $\begin{array}{c}\text { 8x80 PT } \\
\text { (17mm Ply.) }\end{array}$ & $220\left(90^{\circ}\right)$ & $8 \times 350 \mathrm{FT}$ & $83\left(90^{\circ}\right)$ & $83\left(90^{\circ}\right)$ & No \\
\hline CW-3 & $75(16 \%)^{* *}$ & Friction & $\mathrm{n} / \mathrm{a}$ & Friction & $\mathrm{n} / \mathrm{a}$ & $\mathrm{n} / \mathrm{a}$ & No \\
\hline CW-4* & $75(16 \%) * *$ & Friction & $\mathrm{n} / \mathrm{a}$ & Friction & $\mathrm{n} / \mathrm{a}$ & $\mathrm{n} / \mathrm{a}$ & No \\
\hline CW-5 & $75(16 \%)^{* * *}$ & $8 \times 220 \mathrm{FT}$ & 110(Inc.) & $8 \times 220 \mathrm{FT}$ & $82(\mathrm{ST}), 72(\mathrm{SC})$ & $82(\mathrm{ST}), 72(\mathrm{SC})$ & Yes \\
\hline CW-6 & $75(16 \%)^{* *}$ & $\begin{array}{c}\text { 8x160 FT, } \\
\text { 8x80 PT } \\
\text { (22mm Ply.) }\end{array}$ & $\begin{array}{l}248(\text { Inc.) } \\
206\left(90^{\circ}\right)\end{array}$ & $\begin{array}{l}8 \times 200 \mathrm{FT}, \\
8 \times 350 \mathrm{FT}\end{array}$ & $\begin{array}{c}42(\mathrm{ST}), 36(\mathrm{SC}) \\
78\left(90^{\circ}\right)\end{array}$ & $\begin{array}{c}34(\mathrm{ST}), 36(\mathrm{SC}), \\
78\left(90^{\circ}\right)\end{array}$ & Yes \\
\hline CW-7* & $25(5 \%)^{* *}$ & $\begin{array}{c}8 x 80 \text { PT } \\
\text { (17mm Ply.) }\end{array}$ & $220\left(90^{\circ}\right)$ & $8 \times 350 \mathrm{FT}$ & $83\left(90^{\circ}\right)$ & $83\left(90^{\circ}\right)$ & Yes \\
\hline
\end{tabular}

* indicates bi-directional loading protocol

** yield percentage of post-tensioning bar

PT - partially threaded screw, FT - fully threaded screw

Ply. - plywood as per NZS3603 (Standards New Zealand 1993)

(ST)-shear-tension screw, (SC)-shear-compression screw, Inc.-inclined screw, $90^{\circ}$ - screw installed at 90 degrees

After each test, all of the screws would be removed from the specimen and new screws were installed in a different location following the minimum spacing requirement as per Eurocode 5 (2014). As the damage in the CLT walls was very localized, it was possible to run a number of tests by shifting the screw locations without impairing the connection behaviour significantly. This is also one advantage of using STS connections in mass timber products such as CLT to improve repairability. 


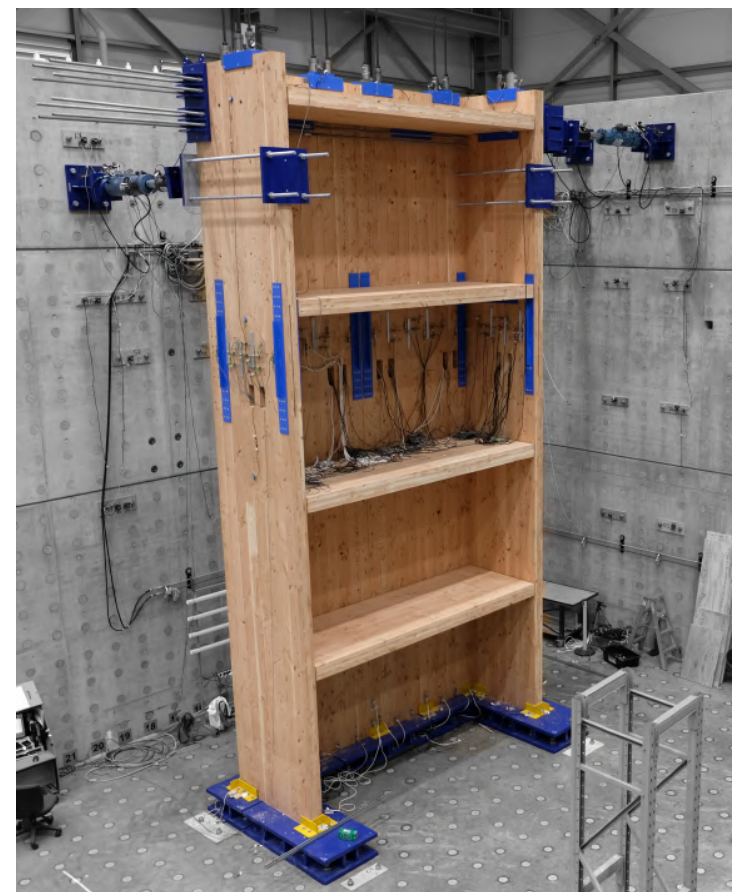

(a) Core-wall Test Overall View

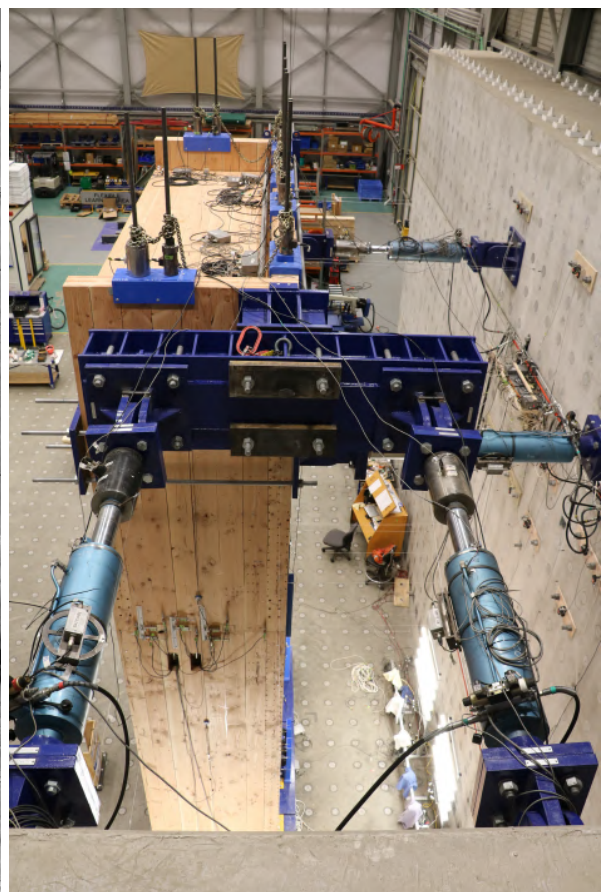

(b) Core-wall Loading Elevation View

Fig. 7. Experimental Test Set-up

Fig. 7(b) shows how the specimen was loaded with actuators. Along the strong axis, two 700kN actuators with 8-M30 Grade 8.8 threaded rods were used to apply the lateral loads via a steel loading beam and bearing head at a wall height of $8.2 \mathrm{~m}$. Along the weak axis, each flange wall was loaded by one $700 \mathrm{kN}$ actuator with 4-M36 Grade 8.8 threaded rods at a wall height of $7.4 \mathrm{~m}$. Fig. 8 shows the two loading protocols used in the testing. There was non-zero drift in the orthogonal direction for both loading protocols to account for the arc that was induced by transverse displacement to an orthogonal actuator. For example with reference to Fig. 8a, during uni-directional strong axis loading the actuators connected to each flange wall were required to extend during positive and negative strong axis drift to maintain in-plane movement of the core-wall. The displacement controlled loading followed the ACI ITG-5.1-07 special protocol for post-tensioned precast structural walls (ACI Innovation Task Group 5 2008). The amplitude of each subsequent cycle group was 1.25 times the previous cycle group, and each cycle group had three identical cycles. For Tests CW-4 and CW-7, one cycle group of uni-directional loading was followed by cloverleaf bi-directional loading. These drifts were chosen during each test upon evaluation of the actual CLT compression strains and visible damage at the wall base. For the final tests, the specimen was tested until either a connection failure occurred or the actuator stroke limit (i.e., 2.3\% wall drift ratio) was reached. 


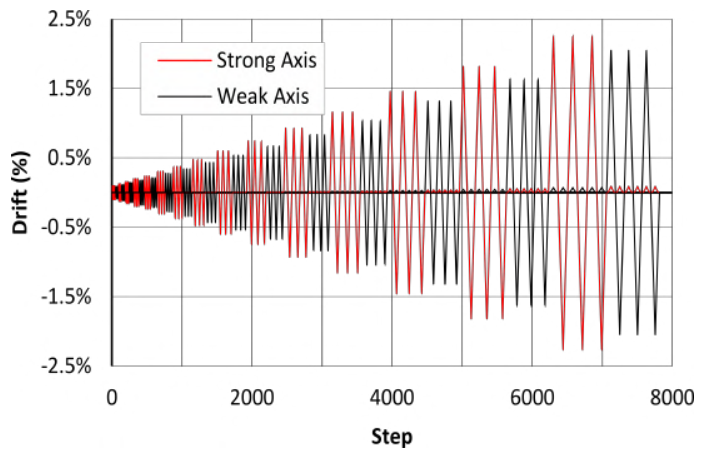

(a) Uni-directional Loading Protocol

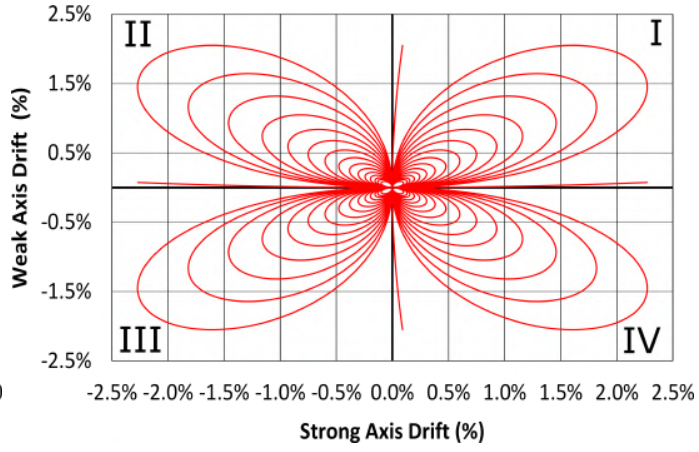

(b) Bi-directional Loading Protocol

Fig. 8. Experimental Loading Protocols

\section{Torsional Restraints}

The asymmetric "C" shape of the core-wall along the strong axis meant eccentricity and therefore torsional restraints were required when loading along the strong axis. Torsional restraints were then provided by shear keys at the base, blue vertical steel straps at the castellation level (shown in Fig. 7(a)), and by the actuators on each flange along the weak axis. The blue vertical straps were fastened only to the section of wall below the castellation, and extended above the castellation to provide restraint. Further restraints to twisting were provided by the floor diaphragms.

\section{Instrumentation and Key Design Parameters}

In total, 220 linear variable differential transducers (LVDTs), 16 load cells, and 20 inclinometers were installed to measure the core-wall response. As an example, Fig. 9 shows the instrumentation to measure core-wall response at one floor level with the castellated horizontal joints and at the base level. Instruments were placed on the specimen at $2 \mathrm{~m}$ inter-storey heights when practicable. The actuators had $1000 \mathrm{kN}$ load cells to monitor the applied load, and the post-tensioning forces were monitored on each high strength bar with $500 \mathrm{kN}$ load cells. As the post-tensioning bars were placed in pairs, the results of each pair were combined. The potentiometers measured in-plane and out-of-plane wall movement, neutral axis depth (i.e., length of the compression zone) at the wall base, core-wall base sliding, wall joint relative slip, castellation movement, diaphragm connection movement, and UFP connection movement. Inclinometers measured wall and floor rotations.

\section{TESTING RESULTS AND DISCUSSION}

The key test results along the strong axis loading are reported in Table 4. The table contains experimental results at the Serviceability Limit State (SLS) level, defined herein as $0.33 \%$ inter-storey drift ratio, and Peak Drift level. AS/NZS 1170.0 Appendix C (2002) specifies SLS of $0.33 \%$ for 


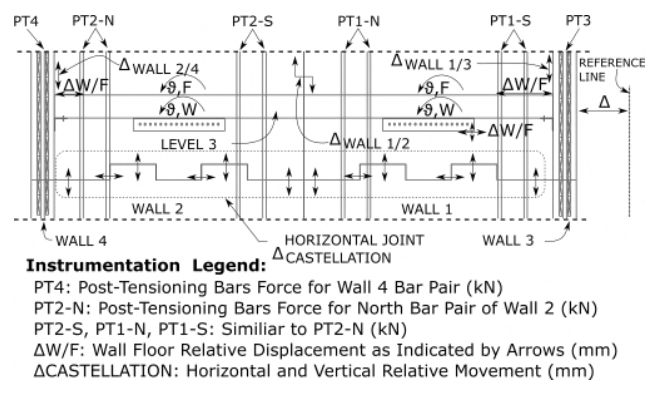

(a) Floor Level Instrumentation

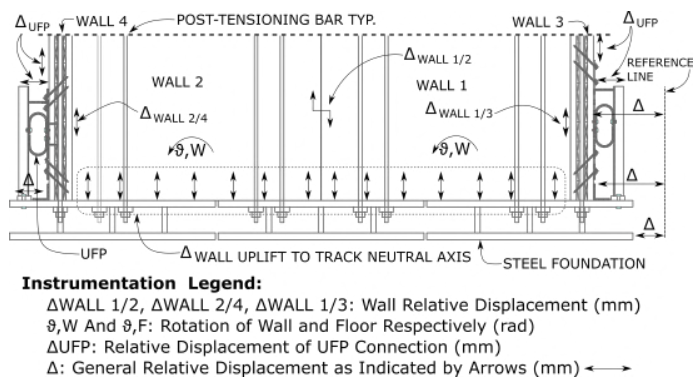

(b) Base Level Instrumentation

Fig. 9. Key Test Instrumentation

plaster/gypsum walls which is common in NZ timber buildings. In Tests CW-1, CW-3 and CW-4, Peak Drifts were limited to avoid significant damage to the compression toe at the wall base. During Test CW-2, a Peak Drift of $1.5 \%$ was deemed sufficient to capture the core-wall behaviour while also minimizing compression toe damage for upcoming tests. Test CW-5 Peak Drift was limited due to tensile failure of screws at the in-plane joint which will be discussed and Tests CW-6 and CW-7 Peak Drifts were limited by the actuator's stroke limit.

Table 4. Experimental Data Results: Summary of Strong Axis Loading

\begin{tabular}{|c|c|c|c|c|c|c|c|c|c|c|c|c|c|c|c|}
\hline \multirow[b]{2}{*}{ Test } & \multicolumn{5}{|c|}{ Serviceability Limit State } & \multicolumn{10}{|c|}{ Peak Drift } \\
\hline & $\begin{array}{c}\text { CA } \\
\%\end{array}$ & $\begin{array}{c}\mathbf{F} \\
\mathrm{kN}\end{array}$ & $\begin{array}{c}\mathbf{k} \\
\mathrm{kN} / \mathrm{mm}\end{array}$ & $\begin{array}{c}\text { vp,web } \\
\%\end{array}$ & $\begin{array}{c}\text { vp,fl } \\
\%\end{array}$ & $\begin{array}{c}\text { Drift } \\
\%\end{array}$ & $\begin{array}{c}\text { CA } \\
\%\end{array}$ & $\begin{array}{c}\mathbf{F} \\
\mathrm{kN}\end{array}$ & $\begin{array}{c}\mathbf{k} \\
\mathrm{kN} / \mathrm{mm}\end{array}$ & $\begin{array}{c}\text { vp,web } \\
\%\end{array}$ & $\begin{array}{c}\text { vp,fl } \\
\%\end{array}$ & $\begin{array}{c}\text { Ed } \\
\mathrm{kN}-\mathrm{mm}\end{array}$ & $\begin{array}{c}\delta_{\mathbf{r}, \mathbf{w 1}} \\
\%\end{array}$ & $\begin{array}{c}\delta_{\mathbf{s l}, \mathbf{w 1}} \\
\%\end{array}$ & $\begin{array}{c}\delta_{\mathbf{s h}+\mathbf{b}, \mathbf{w 1}} \\
\%\end{array}$ \\
\hline CW-1 & 12 & 60 & 2.2 & 11 & 6 & 1.2 & 9 & 154 & 1.6 & 35 & 15 & 39672 & 90 & 1 & 9 \\
\hline CW-2 & 43 & 179 & 6.5 & 21 & 20 & 1.5 & 26 & 375 & 3.2 & 48 & 39 & 208701 & 68 & 5 & 27 \\
\hline CW-3 & 9 & 77 & 2.8 & 22 & 17 & 0.7 & 14 & 140 & 2.3 & 32 & 19 & 15637 & 82 & 2 & 16 \\
\hline CW-4 & 9 & 76 & 2.8 & 21 & 17 & 0.8 & 13 & 146 & 2.2 & 33 & 23 & 10418 & 88 & 2 & 12 \\
\hline CW-5 & 61 & 230 & 8.4 & 20 & 21 & 1.2 & 57 & 555 & 5.8 & 41 & 43 & 239741 & 58 & 5 & 37 \\
\hline CW-6 & 65 & 242 & 8.9 & 21 & 21 & 2.3 & 49 & 845 & 4.5 & 68 & 73 & 707022 & 61 & 4 & 35 \\
\hline CW-7 & 44 & 128 & 4.7 & 12 & 10 & 2.3 & 22 & 460 & 2.5 & 58 & 45 & 333166 & 73 & 3 & 24 \\
\hline
\end{tabular}

CA - Composite Action as defined by Eq. 1 $\mathrm{k}$ - secant stiffness $\mathrm{vp}$, web \& vp,fl - Yield percentage of web and flange extreme post-tensioning bar respectively Ed - Total energy dissipation during full loading protocol $\delta_{\mathbf{r}, \mathbf{w 1}}$ - rocking deformation percentage; $\delta_{\mathbf{s l}, \mathbf{w 1}}$ - sliding deformation percentage; $\delta_{\mathbf{s h}+\mathbf{b}, \mathbf{w 1}}$ - shear and bending deformation percentage, of total Wall 1 deformation

The partial composite action (CA) of the experimental core-wall tests is presented by comparing test results with theoretical non-composite and fully composite systems in a similar manner to composite beams, as shown in Eq. 1 (Gutkowski et al. 2008; Pault and Gutkowski 1977).

$$
\% C A_{\delta}=\frac{F_{T e s t, \delta}-F_{0 \%, \delta}}{F_{100 \%, \delta}-F_{0 \%, \delta}}
$$

where, for a given drift $(\delta), F_{0 \%, \delta}$ is the theoretical force for a fully non-composite section, $F_{100 \%, \delta}$ is the theoretical force for a fully composite section, and $F_{T e s t, \delta}$ is the measured force. The theoretical calculations are based on a (unbonded) post-tensioned rocking wall boundary condition following the 
Monolithic Beam Analogy (MBA) design procedure initially proposed by Pampanin et al. (2001) for precast concrete, extended by Palermo (2004) to capture the elastic range and adopted by Newcombe et al. (2008) for timber. For the fully non-composite section, the theoretical force was determined considering only the two in-plane web walls acting as single post-tensioned walls with no composite action contribution from fasteners or friction. For the fully composite section, rigid connections between all flange and web walls were considered and the effective flange width was considered as the full length of the flange wall. The theoretical calculations considered bending, shear, and rocking deformations. No sliding deformation was considered. The post-tensioned timber walls were designed in accordance with the Pres-Lam design guide (Pampanin et al. 2013) which provides further details on the use of the MBA with timber. Fig. 10 shows the changing composite action at each drift level for each test. The highest CA was observed in Test CW-6, where CA at $0.33 \%, 1.5 \%$, and $2.3 \%$ drift were $65 \%, 62 \%$, and $49 \%$ respectively. This gradual decrease in composite action with increased wall drift was also observed in Tests CW-2 and CW-7 and is indicative of the stiffness degradation of the screwed connections at the orthogonal and the in-plane joints. A sudden drop of CA in Test CW-5 occurred when tensile failure of screws at the in-plane joint occurred. This will be further discussed in this paper. The low CA values reported in Tests CW-1, CW-3, and CW-4 are indicative of the friction contribution that occurred which had been noted previously by Moroder et al. (2018).

The secant stiffness values at given drift levels in Table 4 include all possible slip and translation sliding due to the tolerances between the CLT wall panels. The SLS stiffness of 2.2, 2.8, and $2.8 \mathrm{kN} / \mathrm{mm}$ achieved in Tests CW-1, CW-3, and CW-4 respectively represent a lower bound for this post-tensioned CLT core-wall system. The significant change in stiffness for Tests CW-2, CW-5 and CW-6 indicated the impact connection detailing choice has on the system behaviour. In Test CW-6, the SLS stiffness was 8.9 $\mathrm{kN} / \mathrm{mm}$, almost four times of that achieved in Test CW-1.

The kinematics of the post-tensioned CLT core-wall was also dependent on the connection detailing chosen between the CLT wall panels. The deformation contributions listed are in reference to the displacement/drift at wall height $8.2 \mathrm{~m}$. For CW-6 using the mixed angle screwed connections, individual contributions to the total wall drift due to rocking, sliding, and shear and bending were $61 \%, 4 \%$ and $35 \%$ respectively. They were $82 \%, 2 \%$ and $16 \%$ respectively for the comparable Test CW-3. The observation was different from past conventional CLT shear wall testing by Gavric et al. (2015) where the combined contribution of in-plane shear and bending deformation was less than $5 \%$ and the wall drift was mainly caused by rigid body movement of CLT due to rocking and horizontal sliding. Therefore, this experimental study indicated that the post-tensioned CLT core-wall with careful connection detailing was able to provide more efficient utilization of strong and stiff CLT panels when compared to conventional 

reported by Sarti et al. (2016) with post-tensioned LVL single wall testing.

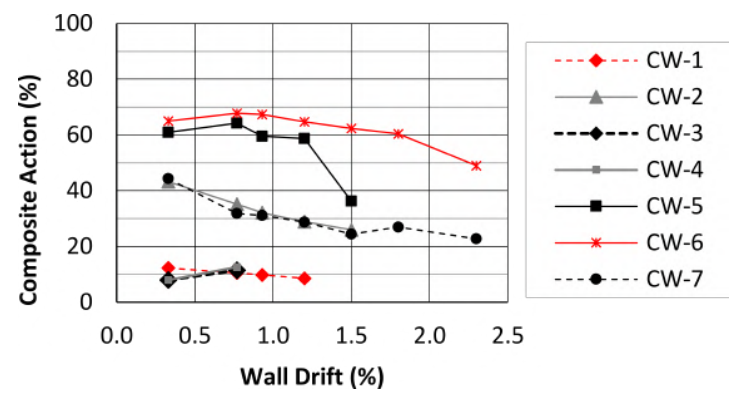

Fig. 10. Composite Action Summary

\section{Fig. 10. Composite Action Summary}

CLT shear walls. The bending and shear deformation contribution of $35 \%$ was comparable to that

\section{Global Post-tensioned Core-wall Response}

\section{Core-wall Behaviour along Strong Axis}

All tests displayed non-linear geometric elastic behaviour, typical of post-tensioned rocking systems. In Tests CW-1, CW-3 and CW-4 very low energy dissipation was observed which was due to friction between the panels and minor post-tensioning losses. Residual drifts for Tests CW-1, CW-3, and CW-4 were negligible. Post-tensioning losses at the end of each test were 5\% (Web Walls) and 22\% (Flange Walls) for Test CW-1, but negligible for Tests CW-3 and CW-4 respectively. The initial post-tensioning force was approximately 5\% for Tests CW-1 and CW-7 versus $10 \%$ for Tests CW-2 through CW-6, respectively, per NSZ3603 (1993). 

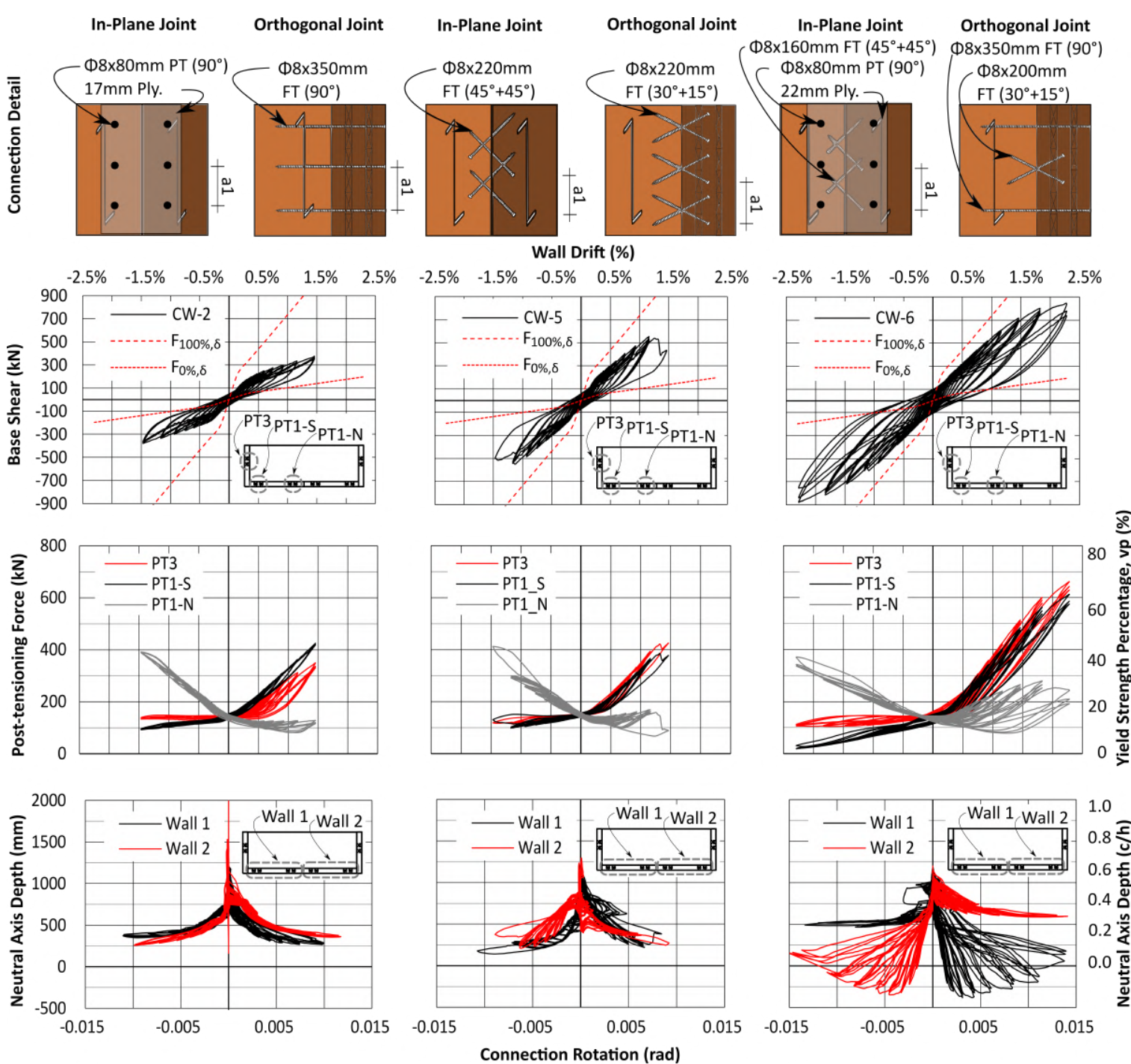

(a)

(b)

(c)

Fig. 11. Key Strong Axis Experimental Results: (a) Test CW-2 (b) Test CW-5 (c) Test CW-6

Fig. 11 shows selected key plots from Tests CW-2, CW-5, and CW-6. The base shear-wall drift plots compare test results to the theoretical fully composite, $F_{100 \%, \delta}$, and fully non-composite, $F_{0 \%, \delta}$, core-wall. Similar to CW-1, CW-3 and CW-4, a typical non-linear elastic behaviour due to wall gap opening was observed. The initial slip in each test before yielding was observed because of the residual deformation developed at the wall bases, sliding, compression perpendicular to grain of the flange walls and the tolerances at the wall base. In Test $\mathrm{CW}-6$, peak sliding was $24 \mathrm{~mm}$ at $\pm 2.3 \%$ drift. With reduced screw spacing and the use of inclined screws, the core-wall strength, stiffness, and energy dissipation increased significantly. In particular, the use of mixed angle screws led to enhanced displacement capacity and energy dissipation. In Test CW-6 at $2.3 \%$ drift, a peak load of $845 \mathrm{kN}(\approx 7000 \mathrm{kN}-\mathrm{m}$ overturning 


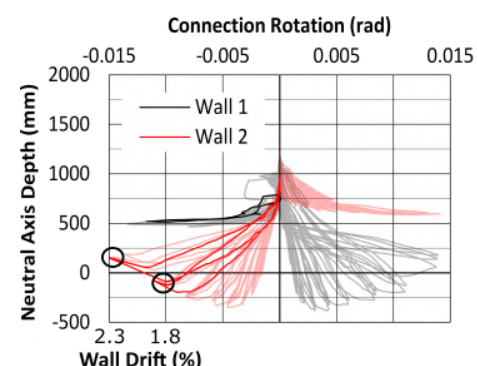
to show the displaced shape more clearly.

moment at the core-wall base) was achieved. At this drift level, a maximum load of $85 \mathrm{kN}$ was recorded in the actuators along the weak axis to provide torsional restraints.

In Fig. 11 the post-tensioning force-drift curves are only shown for walls 1 and 3 as similar responses in walls 2 and 4 were observed due to the symmetrical wall layout, shown in Fig. 1. The increase in post-tensioning forces in wall 3 from Test CW-2 to CW-6 showed the increased stiffness and composite action due to the enhanced orthogonal joint. In Test CW-6, the post-tensioning forces were higher in the flange wall 3 when compared to the web wall 1. The similar post-tensioning decrease in PT1-S and PT3 for each cycle at $2.3 \%$ drift in Test CW-6 indicated the stiffness degradation in the in-plane vertical joint. Average post-tensioning losses for each test considering all unbonded bars were 9\% (CW-2), $2 \%(\mathrm{CW}-5)$, and 9\% (CW-6) of initial post-tensioning force respectively.

The change of the neutral axis depth (c) compared to wall length (h) in Tests CW-2 and CW-5 showed that both wall 1 and wall 2 were in contact with foundation throughout the tests. In Test CW-6, the negative neutral axis depth indicated there was wall uplift, which is unique behaviour when it is compared with past post-tensioned coupled wall testing. As illustrated in Fig. 12, when the core-wall drift increased from the SLS level $0.33 \%$ to $1.8 \%$, web wall 2 was lifted off the foundation. This was due to the high strength and stiffness of the in-plane joint. However, at $2.3 \%$ wall drift, the increased shear demand on the in-plane joint from increased post-tensioning forces and shear flow due to composite action was greater than the capacity of the mixed angle screwed connection. During the entire second and third $2.3 \%$ wall drift cycles, wall 2 was in contact with the foundation. This is shown as a positive neutral axis and by the lower post-tensioning forces of PT1-S, PT1-N and PT3 of Fig. 11(c). In all tests in general, the shifting of the neutral axis at each drift cycle and the differences between load and unload cycles is indicative of the screwed connections with pinching behaviour and stiffness degradation. Fig. 12 is vertically exaggerated

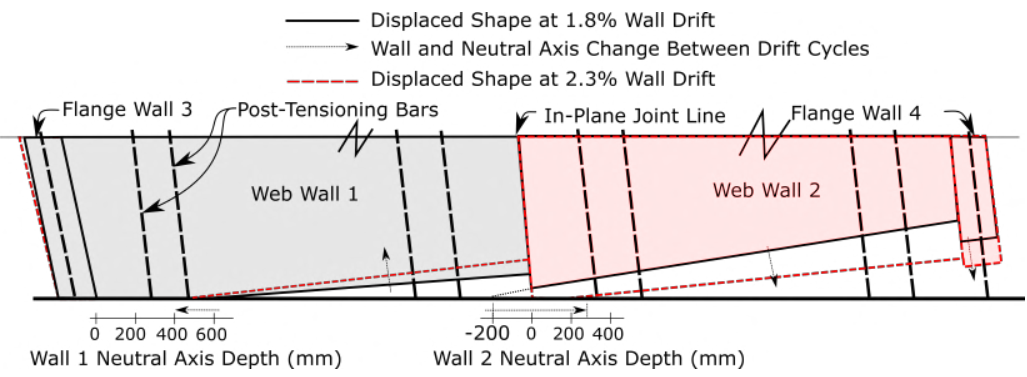

Fig. 12. Test CW-6: Changing Neutral Axis

At the end of each test, total residual drifts which included base sliding due to tolerances, relative joint slip, and timber crushing were $0.2 \%(\mathrm{CW}-2), 0.2 \%(\mathrm{CW}-5)$, and $0.5 \%(\mathrm{CW}-6)$ respectively. The 
contribution of base sliding in total residual drift was $0.1 \%$ for Test CW-2 and CW-5, and $0.2 \%$ for Test CW-6. The increased residual drift of Test CW-6 was primarily due to yielding of the screwed connections along the orthogonal and in-plane joints where there was an average residual joint slip of more than $3 \mathrm{~mm}$. In Test CW-6, residual drift was negligible until the $1.8 \%$ drift cycle where it was $0.3 \%$. Increasing the initial post-tensioning level might be able to reduce the residual drifts. However, the compressive stress level in wood should remain relatively low to avoid the long-term loaded timber creep effect (Ranta-Maunus 1975). While a creep model has been developed for CLT (Nguyen et al. 2019) and a design approach to predict post-tensioning losses in a post-tensioned LVL or glulam frame building has been developed and quantified (Granello et al. 2018a; Granello et al. 2018b), further research is required for post-tensioned CLT wall structures. Fig. 13 shows that damage was concentrated to the compression toes of the wall base. Particle Tracking Technology was implemented at the core-wall base to capture displacement and strain fields and results presented in Brown et al. (2020) show that the flange engagement lessens with increasing distance from the orthogonal joint. Further, out-of-plane flange wall rotation occurred and in Test CW-2, only $50 \mathrm{~mm}$ of the $175 \mathrm{~mm}$ flange cross-sectional thickness was in contact with the foundation at the orthogonal joint interface. As such, it was observed that less flange engagement occurred than that assumed in the analytical fully composite section. A discussion on wall base behaviour can be found in Brown et al. (2020) and further work is required to determine an effective flange width for post-tensioned mass timber core-walls. At 2.3\% drift in Test CW-6, local compression crushing and rippling occurred at the web wall corners, indicative of plastic strain behaviour. Though no significant load drop due to this was observed during its first incidence in the first $2.3 \%$ drift cycle, an increased neutral axis depth occurred in the second and third drift cycle as shown in Fig. 11c which can be attributed to plastic compressive strain behaviour and connection slips, which will be discussed later. The plastic behaviour at the wall base also contributed to residual drift.

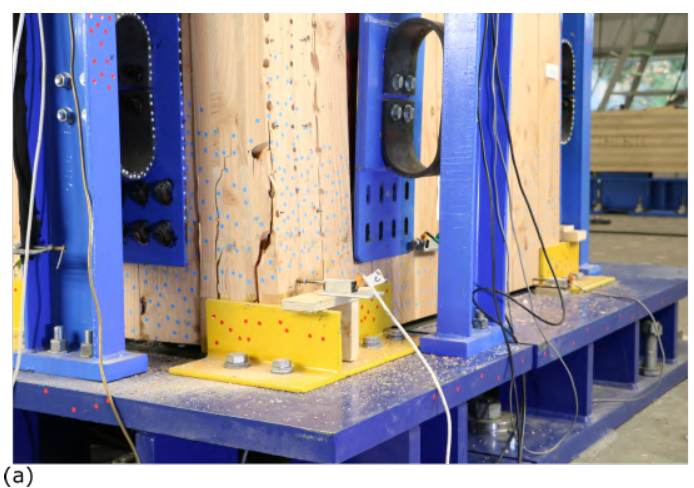

Fig. 13. CLT Wall Base Crushing (a) During and (b) After Testing

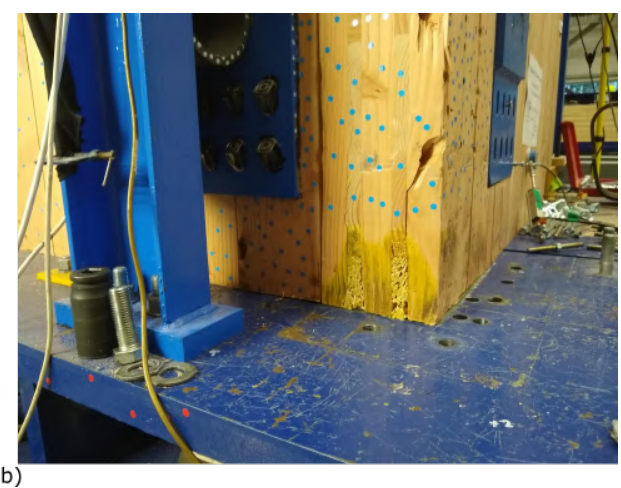

(b)

\section{of}




\section{Bi-directional Loading and Global Wall Behaviour along the Weak Axis}

Test CW-7 which followed the uni-directional (Uni-Dir.) and cloverleaf (Bi-Dir.) loading protocol is shown in Fig. 14. During loading along the strong axis, a similar response between uni-directional and bi-directional loading was found. For loading along the weak axis, differences between the hysteresis loop and strength are reported, especially during loading in quadrant I and II of Fig. 8(b). Although stable system level performance was observed and no significant differences were observed in the compressive behaviour of the flanges, further research is required to quantify these effects. As expected, the stiffness was much lower and unsymmetrical along the weak axis uni-directional loading. Web walls 1 and 2 were engaged accordingly to the orthogonal joint connection stiffness. Tests CW-5 and CW-6 reached similar peak loads of $300 \mathrm{kN}$, however the mixed angle connection provided increased energy dissipation. When the web walls were engaged in tension, post-tensioning forces increased accordingly indicating the web wall uplift. The average post-tensioning loss for Test CW-7 was $6 \%$ of initial post-tensioning force.

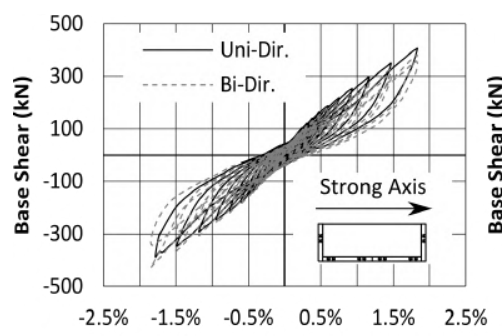

(a)

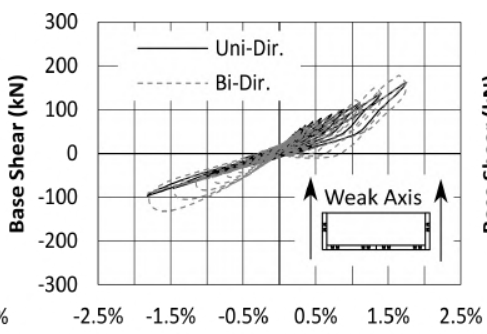

(b)

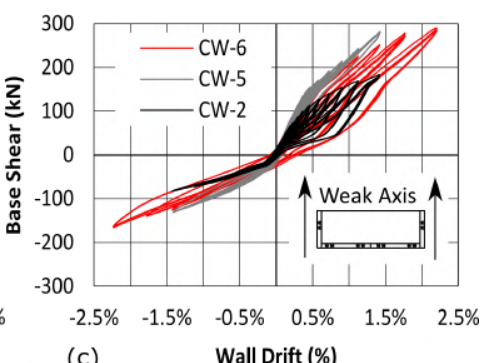

(c)

Fig. 14. Force-displacement: (a) Test CW-7 bi-directional strong axis (b) Test CW-7 bi-directional weak axis (c) uni-directional weak axis

\section{Connection Behaviour}

The screwed connection details for the in-plane and orthogonal joints had primary influence on the core-wall system strength, stiffness, and displacement capacity. Other than screwed connections, the castellations provided a strong and stiff horizontal joint, the diaphragm connection decoupled the wall-floor displacement incompatibility well, and each UFP connection performed well.

\section{Screwed Connections}

In the strong axis, Fig. 15 shows the varying relative joint slips. At $0.75 \%$ drift, the relative slips in the in-plane joint were $13 \mathrm{~mm}$, to $11 \mathrm{~mm}, 6.6 \mathrm{~mm}$ and $5 \mathrm{~mm}$ for Tests CW-3, 2, 5 and 6 respectively. The relative slips in the orthogonal joints were $8.5 \mathrm{~mm}, 4 \mathrm{~mm}, 1 \mathrm{~mm}$ and $1.5 \mathrm{~mm}$ for Tests CW-3, 2, 5 and 6 respectively. In Test CW-5 in the 1.5\% drift cycle group, the in-plane relative joint slip increased from $12 \mathrm{~mm}$ to $20 \mathrm{~mm}$ as a result of tensile failure in multiple inclined screws. The $12 \mathrm{~mm}$ ultimate displacement capacity of the joint was similar to findings from Hossain et al. (2016). By using the mixed angle screwed 


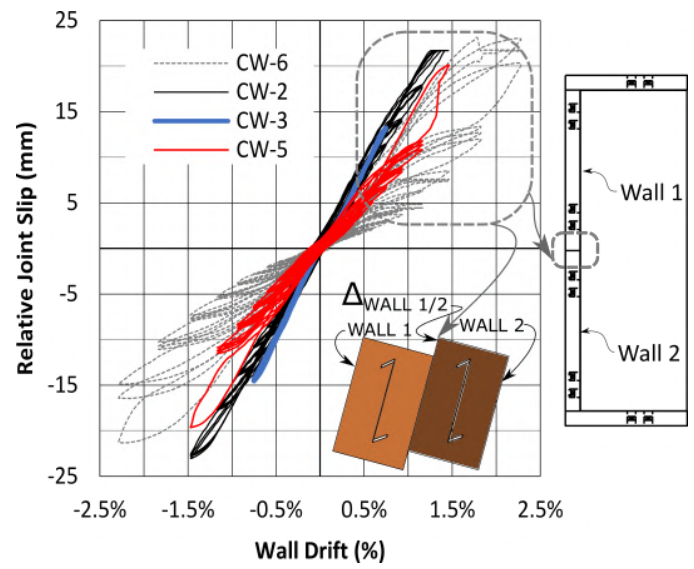

(a) In-plane Joint Test Comparison high loads, which is shown in Fig. 16(a).

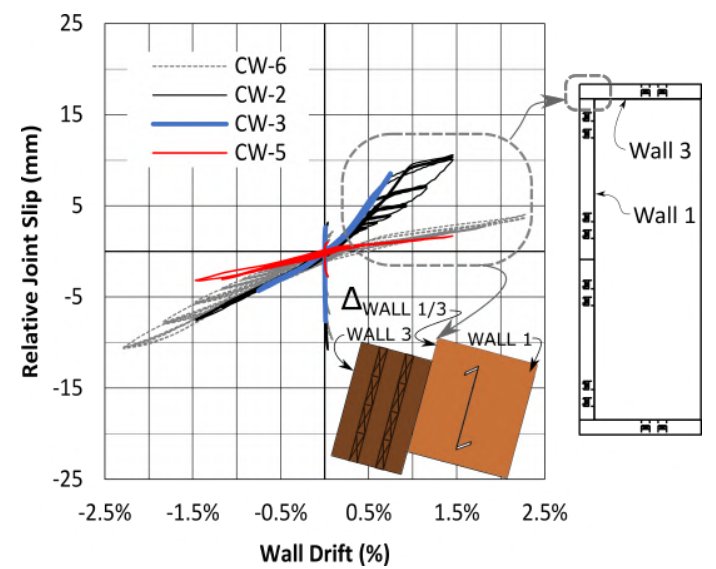

(b) Orthogonal Joint Test Comparison

Fig. 15. Strong Axis Relative Joint Slip Behaviour

connections in Test CW-6, the displacement capacity of the connections exceeded 20mm while sustaining

Fig. 15. Strong Axis Relative Joint Slip Behaviour inclined screws in Test CW-5 had limited displacement and energy dissipation capacity. In Test CW-6, the mixed angle screwed connections were implemented for the orthogonal and in-plane joints. This resulted in increased displacement capacity, energy dissipation capacity, and ultimately prevented a sudden loss in stiffness caused by brittle tensile failure of the screws. Table 5 provides the fraction of each screw type that failed in each test. As per Table 3, in Test CW-6 the orthogonal joint between wall 2 and wall 4 had $20 \%$ less inclined shear-tension screws than the joint between wall 1 and wall 3 . As a result, more shear-tension screws failed on the joint between wall 2 and wall 4, and Fig. 16(b) shows the distinct difference in the positive joint displacement. Increased displacement and energy dissipation is shown for the orthogonal joint between wall 2 and wall 4 but there was no notable difference between the positive and negative cycles of the global hysteresis loop in Fig. 11(c). In both orthogonal joints, the mixed angle screwed connections provided stable connection and system performance. Fig. 17 shows the images of wood crushing in CLT and screws bending in the in-plane and orthogonal joints after the tests. 


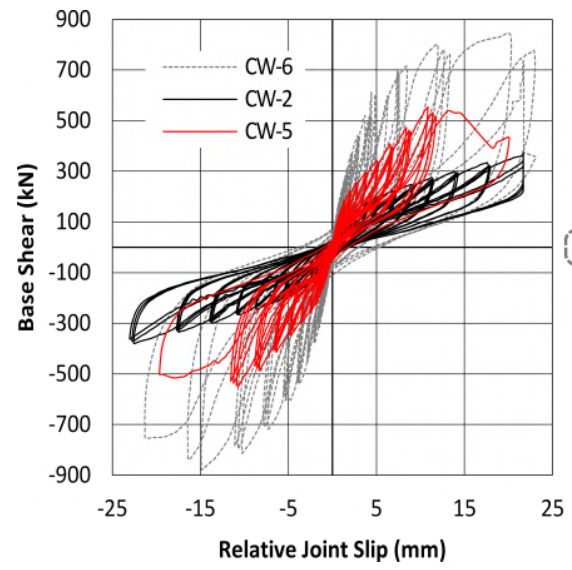

(a) In-plane Joint Slip Behaviour

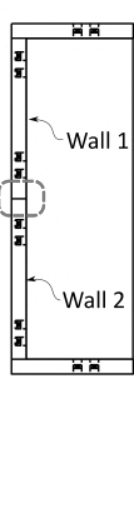

Fig. 16. Joint Force-Displacement Behaviour

Table 5. Screw Tensile Failure Summary

\begin{tabular}{cccc}
\hline Test & $\begin{array}{c}\text { In-plane Joint } \\
\text { Wall 1/2 Joint }\end{array}$ & $\begin{array}{c}\text { Orthogonal Joint } \\
\text { Wall 1/3 Joint }\end{array}$ & $\begin{array}{c}\text { Orthogonal Joint } \\
\text { Wall } 2 / 4 \text { Joint }\end{array}$ \\
\hline CW-2 & $12 / 220\left(90^{\circ}\right)$ & $3 / 83\left(90^{\circ}\right)$ & $1 / 83\left(90^{\circ}\right)$ \\
CW-5 & $95 / 110($ Inc.) & $0 / 154($ Inc.) & $0 / 154($ Inc.) \\
CW-6 & $43 / 248\left(\right.$ Inc.), $1 / 206\left(90^{\circ}\right)$ & $8 / 42(\mathrm{ST}), 0 / 36(\mathrm{SC}), 3 / 78\left(90^{\circ}\right)$ & $21 / 34(\mathrm{ST}), 2 / 36(\mathrm{SC}), 3 / 78\left(90^{\circ}\right)$ \\
CW-7* & $73 / 220\left(90^{\circ}\right)$ & $19 / 83\left(90^{\circ}\right)$ & $29 / 83\left(90^{\circ}\right)$ \\
\hline
\end{tabular}

* indicates bi-directional loading protocol

(ST)-shear-tension screw, (SC)-shear-compression screw, (Inc.)-inclined screw, $\left(90^{\circ}\right)$-screw installed at 90 degrees

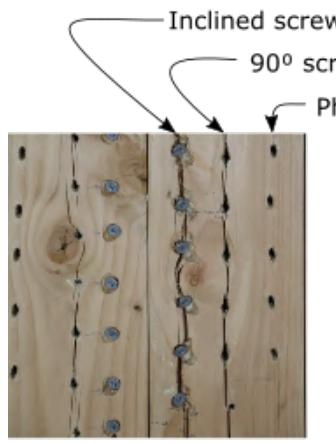

(a) In-plane joint

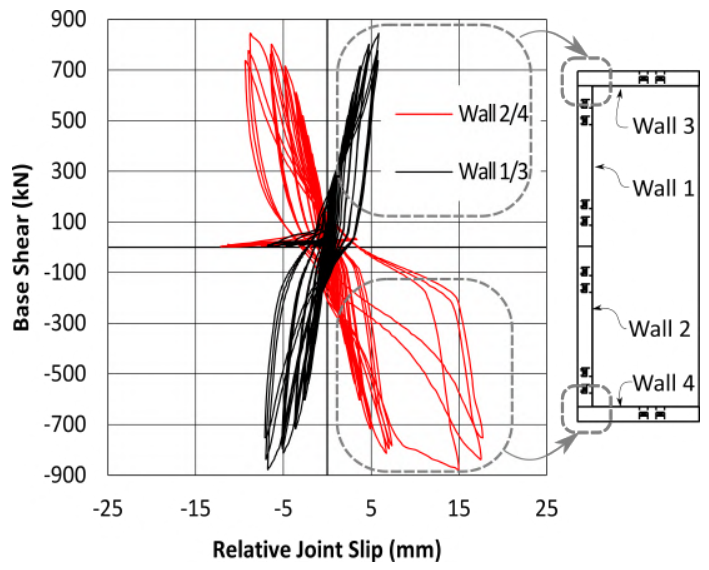

(b) Test CW-6: Orthogonal Joint Slip Behaviour 
2 connections was found to be sufficient and ensured the screws remained elastic throughout the test programme. In Test CW-7, vertical displacement of each connection type UFP 1, UFP 2, and UFP 3 were $2.1 \mathrm{~mm}, 1.5 \mathrm{~mm}$ and $0.4 \mathrm{~mm}$ during peak core-wall drift of $2.3 \%$ and wall base uplift of approximately $25 \mathrm{~mm}$. While the UFP 3 epoxied plate connection had the least connection slip, the inclined screwed connection had advantages to accommodate bi-directional movement. When any wall movement other than vertical occurred (horizontal or out-of-plane), the inclined screwed connections behaved in dowel action with observed lower stiffness than the epoxied connection. For example, during Test CW-6 strong axis loading, total horizontal base sliding of $25 \mathrm{~mm}$ at $2.3 \%$ core-wall drift caused UFP 1 connection plate to translate horizontally $8 \mathrm{~mm}$ and rotate 0.007 radians. This UFP 1 connection plate movement would have reduced any out-of-plane stresses in the UFP while in contrast, the UFP 3 connection plate had less than $0.5 \mathrm{~mm}$ translation and no rotation. The $2-\phi 12 \mathrm{~mm}$ threaded rods were implemented for Tests CW-5 and CW-6 but not implemented for Test CW-7. During Test CW-6, at 2.3\% drift during strong-axis loading, one UFP 3 connection plate failed and detached from the flange wall. How significant a contribution the $2-\phi 12 \mathrm{~mm}$ threaded rods had to this failure by creating a stiff load path to separate the connection plate from the flange wall could not be determined because it was found afterwards that the connection plate bonding surface had some deficiency due to mill scale. During Test CW-7 UFP 3 connection plate failure did not occur and greater than $10 \mathrm{~mm}$ out-of-plane displacement was observed between the connection plate and the PFC. While no brittle failure of a UFP occurred during the test programme, a UFP connection plate failure occurred which could be at least partially attributed to displacement incompatibilities which arise from any wall movement other than vertical. The limited studied herein showed that screwed connections could provide targeted vertical connection stiffness while accommodating horizontal and out-of-plane wall movement.

\section{CONCLUSIONS}

This paper reported the experimental test results of a post-tensioned flanged C-shaped CLT corewall. The flanged walls form a partial composite shear wall system and increase the lateral strength and stiffness. The results confirmed that improved shear wall behaviour could be achieved through proper connection detailing between the walls. The STS connections with mixed angle installations for the in-plane and orthogonal joint offered one effective connection solution for such a core-wall system. It was also found that different levels of partial composite action could be achieved based on the different connection methodologies. The key findings are summarized as follows:

- Test CW-6 showed that wall uplift occurred during the rocking motion. This resulted in the highest core-wall composite action of approximately two-thirds and the SLS drift stiffness was 
almost four times when compared to decoupled Test CW-1.

- Mixed angle screwed connections provided stable system performance for Test CW-6 at a core-wall drift of $2.3 \%$, which was at the stroke limit of the actuators. While inclined screws can provide high strength and stiffness, mixed angle screwed connections on the in-plane and orthogonal joints provided necessary additional displacement and energy dissipation capacity. The partial composite action decreased with increasing core-wall drift and this behaviour was stable with either $90^{\circ}$ or mixed angle screwed connection details.

- Several tests were performed on the wall specimen with only minor damage occurring at the compression toes of the CLT wall panels and in proximity of each screwed connection even at high levels of drift. At the end of each test, all screws were removed and new screws were installed in a different location following minimum spacing in an efficient manner. No significant impairment to the connection behaviour was observed.

- Though stable behaviour was observed in bi-directional loading, further analysis is required to quantify the differences in hysteresis loops and peak forces which occurred when compared to uni-directional loading.

- The combination of post-tensioning to provide moment capacity at the wall base and mixed angle screwed connection details at the in-plane and orthogonal vertical joints to provide a $\mathrm{C}$-shaped CLT core-wall composite behaviour is one effective solution to meet increased stiffness demands of taller timber buildings.

This experimental work provided fundamental information for a better understanding of C-shaped post-tensioned rocking timber walls. However, the authors, given the limited number of tests carried out, intend to further numerically investigate different scenarios through a deep sensitivity analysis on key parameters in order to provide design recommendation for the C-shaped geometrical configuration.

\section{DATA AVAILABILITY STATEMENT}

Some or all data, models, or code that support the findings of this study are available from the corresponding author upon reasonable request.

\section{ACKNOWLEDGEMENTS}

The authors would like to acknowledge the sponsorship of Speciality Wood Products Partnership, New Zealand Douglas-Fir Association, Australian Research Council, SPAX Pacific, BBR Contech and the New Zealand Commonwealth Scholarship and Fellowship Plan. PTL | Structural Consultants is also acknowledged for the use of the Pres-Lam system and patent (Buchanan et al. 2007) in this research. The technical support from Peter Coursey, Russell McConchie, Alan Thirwell and Michael Weavers and 
technical comments from Andrew Dunbar, Daniel Moroder and Michael Newcombe are also gratefully acknowledged.

\section{REFERENCES}

ACI (2011). Building code requirements for structural concrete and commentary. Technical Report ACI 318M-11. American Concrete Institute, Farmington Hills, MI.

ACI Innovation Task Group 5 (2008). “Acceptance criteria for special unbonded post-tensioned precast structural walls based on validation testing and commentary : an ACI standard.

Amini, M. O., van de Lindt, J. W., Rammer, D., Pei, S., Line, P., and Popovski, M. (2018). "Systematic experimental investigation to support the development of seismic performance factors for cross laminated timber shear wall systems." Engineering Structures, 172, 392-404.

Australian / New Zealand Standard (2002). AS/NZS 1170.0 Structural Design Actions Part 0: General Principles. In: Standards Australia, GPO Box 476, Sydney, NSW and Standards New Zealand, Private Bag 2439, Wellington, New Zealand.

Australian / New Zealand Standard (2016). AS/NZS 3679: Steel reinforcing materials. In: Standards Australia, GPO Box 476, Sydney, NSW and Standards New Zealand, Private Bag 2439, Wellington, New Zealand.

Beyer, K., Dazio, A., and Priestley, M. J. N. (2008). "Quasi-Static Cyclic Tests of Two U-Shaped Reinforced Concrete Walls.” Journal of Earthquake Engineering, 12(7), 1023-1053.

Brown, J., Li, M., Nokes, R., Palermo, A., Pampanin, S., and Sarti, F. (2020). “(Forthcoming) Investigating the compressive toe of pos-tensioned CLT core-walls use Particle Tracking Technology." $17^{\text {th }}$ World Conference on Earthquake Engineering, 17WCEE, Sendai, Japan.

Buchanan, A. (2016). "The challenges for designers of tall timber buildings." WCTE 2016 - World Conference on Timber Engineering, Vienna, Austria.

Buchanan, A., Pampanin, S., and Palermo, A. (2007). "An engineering wood construction system for high performance structures using pre-stressed tendons and replaceable energy dissipaters- New Zealand Patent 549029.

Catalyst (2018). "Catalyst Spokane, <http://www.catalystspokane.com/>.

CEN (2014). "Eurocode 5: Design of timber structures-Part 1-1: General-Common rules and rules for buildings.

Chen, Z., Popovski, M., and Iqbal, A. (2020). "Structural Performance of Post-Tensioned CLT Shear Walls with Energy Dissipators.” Journal of Structural Engineering, 146(4).

Constantin, R. and Beyer, K. (2014). "Non-Rectangular RC Walls : A Review on Experimental Investi- 
gations." Proc Second European Conference on Earthquake Engineering, 1-12.

CSA 086 (2019). Engineering design in wood. Canadian Standards Association, Mississauga, ON.

Di Cesare, A., Ponzo, F. C., Nigro, D., Pampanin, S., and Smith, T. (2017). "Shaking table testing of post-tensioned timber frame building with passive energy dissipation systems." Bulletin of Earthquake Engineering, 15(10), 4475-4498.

Dujic, B., Pucelj, J., and Zarnic, R. (2004). "Testing of racking behavior of massive wooden wall panels." Proceedings of CIB W18 Meeting Thirty-Seven, Edinburgh, Scotland.

Dunbar, A., Moroder, D., Pampanin, S., and Buchanan, A. (2014). "Timber core-walls for lateral load resistance of multi-storey timber buildings." World Conference on Timber Engineering.

ETA (2017). ETA-12/0114: SPAX self-tapping screws - screws for use in timber constructions. ETADanmark A/S, Nordhavn, Danmark.

ETA (2018). ETA-07/0046: Macalloy 1030 post tensioning system. European Technical Approval, Charlottenlund, Denmark.

FEMA (2009). Quantification of building seismic performance factors. FEMA P695. FEMA, Washington, D.C.

Flatscher, G., Bratulic, K., and Schickhofer, G. (2015). "Experimental tests on cross-laminated timber joints and walls." Proceedings of the Institution of Civil Engineers - Structures and Buildings, 168(11), $868-877$.

Ganey, R., Berman, J., Akbas, T., Loftus, S., Daniel Dolan, J., Sause, R., Ricles, J., Pei, S., Lindt, J. V. D., and Blomgren, H. E. (2017). "Experimental Investigation of Self-Centering Cross-Laminated Timber Walls.” Journal of Structural Engineering, 143(10).

Gavric, I., Fragiacomo, M., and Ceccotti, A. (2015). “Cyclic Behavior of CLT Wall Systems: Experimental Tests and Analytical Prediction Models." Journal of Structural Engineering, 141(11), 4015034.

Granello, G., Leyder, C., Palermo, A., Frangi, A., and Pampanin, S. (2018a). "Design Approach to Predict Post-Tensioning Losses in Post-Tensioned Timber Frames.” Journal of Structural Engineering, 144(8), 1-13.

Granello, G., Palermo, A., Pampanin, S., Pei, S., and Lindt, J. V. D. (2020). "Pres-Lam Buildings : State-of-the-Art." 146(6), 1-16.

Granello, G., Palermo, A., Pampanin, S., Smith, T., and Sarti, F. (2018b). "The implications of posttensioning losses on the seismic response of pres-lam frames." Bulletin of the New Zealand Society for Earthquake Engineering, 51(2), 57-69.

Green, M. and Taggart, J. (2017). Tall wood buildings: design, construction and performance. Birkhauser, Boston, United States. 
Gutkowski, R., Brown, K., Shigidi, A., and Natterer, J. (2008). "Laboratory tests of composite woodconcrete beams." Construction and Building Materials.

Ho, T. X., Dao, T. N., Aaleti, S., Van De Lindt, J. W., and Rammer, D. R. (2017). "Hybrid System of Unbonded Post-Tensioned CLT Panels and Light-Frame Wood Shear Walls.” Journal of Structural Engineering, 143(2), 1-12.

Holden, T., Devereux, C., Haydon, S., Buchanan, A., and Pampanin, S. (2016). "NMIT Arts and Media Building-Innovative structural design of a three storey post-tensioned timber building." Case Studies in Structural Engineering, 6, 76-83.

Hossain, A., Danzig, I., and Tannert, T. (2016). "Cross-laminated timber shear connections with doubleangled self-tapping screw assemblies.” Journal of Structural Engineering, 142(11).

Hummel, J. (2016). "Displacement-based seismic design for multi-storey cross laminated timber buildings.” Ph.D. thesis, University of Kassel, University of Kassel.

Iqbal, A., Pampanin, S., Palermo, A., and Buchanan, A. H. (2015a). "Performance and Design of LVL Walls Coupled with UFP Dissipaters.” Journal of Earthquake Engineering, 19(3), 383-409.

Iqbal, A., Smith, T., Pampanin, S., Fragiacomo, M., Palermo, A., and Buchanan, A. H. (2015b). "Experimental performance and structural analysis of plywood-coupled LVL walls." Journal of Structural Engineering, 142(2).

Izzi, M., Casagrande, D., Bezzi, S., Pasca, D., Follesa, M., and Tomasi, R. (2018). "Seismic behaviour of Cross-Laminated Timber structures: A state-of-the-art review." Engineering Structures, 170, 42-52.

Kelly, J. M., Skinner, R. I., and Heine, A. J. (1972). "Mechanisms of energy absorption in special devices for use in earthquake resistant structures." Bulletin of the New Zealand Society for Earthquake Engineering, 5(3), 63-73.

Khan, F. and Sbarounis, J. (1964). "Interaction of shear walls and frames in concrete structures under lateral loads." American Society of Civil Engineers, 90.

Lauriola, M. P. and Sandhaas, C. (2006). "Quasi-static and pseudo-dynamic tests on XLAM walls and buildings." Cost E29 Int. Worshop on Earthquake Engineering on Timber Structures, European Cooperation in Science and Technology, Brussels, Belgium.

Loss, C., Hossain, A., and Tannert, T. (2018). "Simple cross-laminated timber shear connections with spatially arranged screws.” Engineering Structures, 173, 340-356.

Mancini, M. J. and Pampanin, S. (2018). "Numerical and Experimental Investigation on Low Damage Steel-Timber Post-Tensioned Beam-Column Connection." $16^{\text {th }}$ European Conference on Earthquake Engineering, 1-12.

McDonnell, E. and Jones, B. (2020). “Performance-Based Engineering Provides Path to More Compelling 
Mass Timber Projects.” Technology Architecture and Design, 4(1), 9-13.

Menegon, S. J., Wilson, J. L., Lam, N. T., and Gad, E. F. (2020a). "Experimental assessment of the ultimate performance and lateral drift behaviour of precast concrete building cores." Advances in Structural Engineering.

Menegon, S. J., Wilson, J. L., Lam, N. T., and Gad, E. F. (2020b). "Experimental testing of innovative panel-to-panel connections for precast concrete building cores." Engineering Structures, 207.

Moroder, D., Pampanin, S., Palermo, A., Smith, T., Sarti, F., and Buchanan, A. (2017). "Diaphragm connections in structures with rocking timber walls." Structural Engineering International: Journal of the International Association for Bridge and Structural Engineering (IABSE), 27(2), 165-174.

Moroder, D., Smith, T., Dunbar, A., Pampanin, S., and Buchanan, A. (2018). "Seismic testing of posttensioned Pres-Lam core walls using cross laminated timber." Engineering Structures, 167, 639-654.

Newcombe, M. P., Pampanin, S., Buchanan, A., and Palermo, A. (2008). "Section analysis and cyclic behavior of post-tensioned jointed ductile connections for multi-story timber buildings." Journal of Earthquake Engineering, 12, 83-110.

Newcombe, M. P., Pampanin, S., and Buchanan, A. H. (2010a). "Global response of a two storey Pres-Lam timber building." New Zealand Society for Earthquake Engineering Conference, 8(28), 8.

Newcombe, M. P., Van Beerschoten, W. A., Carradine, D., Pampanin, S., and Buchanan, A. H. (2010b). "In-plane experimental testing of timber-concrete composite floor diaphragms." Journal of Structural Engineering, 136(11), 1461-1468.

Nguyen, T. T., Dao, T. N., Aaleti, S., Hossain, K., and Fridley, K. J. (2019). "Numerical Model for Creep Behavior of Axially Loaded CLT Panels.” Journal of Structural Engineering, 145(1), 1-15.

Palermo, A. (2004). "Use of controlled rocking in the seismic design of bridges." Ph.D. thesis, Technical Institute of Milan, Milan, Italy.

Palermo, A., Pampanin, S., and Buchanan, A. H. (2006). "Experimental investigations on LVL seismic resistant wall and frame subassemblies." $1^{\text {st }}$ European Conference in Earthquake Engineering and Seismology (ECEES), Geneva, Switzerland, Sept 3-8, paper n.983.

Palermo, A., Pampanin, S., Buchanan, A. H., and Newcombe, M. P. (2005). "Seismic design of multistorey buildings using laminated veneer lumber (LVL)." New Zealand Society for Earthquake Engineering Conference.

Palermo, A., Sarti, F., Baird, A., Bonardi, D., Dekker, D., and Chung, S. (2012). "From theory to practice: Design, analysis and construction of dissipative timber rocking post-tensioning wall system for Carterton Events Centre, New Zealand." Proceedings of the 15 th World Conference on Earthquake Engineering, Lisbon, Portugal, 24-28. 
Pampanin, S., Nigel Priestley, M. J., and Sritharan, S. (2001). "Analytical modelling of the seismic behaviour of precast concrete frames designed with ductile connections." Journal of Earthquake Engineering, 5(3), 329-367.

Pampanin, S., Palermo, A., and Buchanan, A. (2013). Post-Tensioned Timber Buildings - Design Guide Australia and New Zealand. Structural Timber Innovation Company, Christchurch.

Pault, J. and Gutkowski, R. (1977). “Tests and analysis of composite action in glulam bridges', Structural Research report No. 17A.” Report no., Civil Engineering Department, Colorado State University, Ft. Collins, CO.

Pei, S., Dolan, J. D., Zimmerman, R. B., Mcdonnell, E., Line, P., and Popovski, M. (2019a). "From Testing to Codification : Post-tensioned Cross Laminated Timber Rocking Post-tensioned Rocking Wall System." International Network on Timber Engineering Research (INTER) - Meeting fifty-two, $1-14$.

Pei, S., Van De Lindt, J. W., Barbosa, A. R., Berman, J. W., McDonnell, E., Daniel Dolan, J., Blomgren, H. E., Zimmerman, R. B., Huang, D., and Wichman, S. (2019b). "Experimental Seismic Response of a Resilient 2-Story Mass-Timber Building with Post-Tensioned Rocking Walls.” Journal of Structural Engineering, 145(11), 1-15.

Pei, S., Van De Lindt, J. W., Popovski, M., Berman, J. W., Dolan, J. D., Ricles, J., Sause, R., Blomgren, H., and Rammer, D. R. (2016). "Cross-Laminated Timber for Seismic Regions: Progress and Challenges for Research and Implementation.” Journal of Structural Engineering, 142(4).

Pei, S., van de Lindt, J. W., Ricles, J., Sause, R., Berman, J., Ryan, K., Dolan, J. D., Buchanan, A., Robinson, T., and McDonnell, E. (2017). "Development and Full-Scale Validation of ResilienceBased Seismic Design of Tall Wood Buildings: The NHERI Tallwood Project.” Proceedings of the New Zealand Society for Earthquake Engineering Annual Conference, April 27-29, Wellington, New Zealand, 2017.

Pilon, D. S., Palermo, A., Sarti, F., and Salenikovich, A. (2019). "Benefits of multiple rocking segments for CLT and LVL Pres-Lam wall systems." Soil Dynamics and Earthquake Engineering, 117, 234-244.

Popovski, M., Schneider, J., and Schweinsteiger, M. (2010). "Lateral load resistance of cross-laminated wood panels." WCTE 2010, Vol. 4, Riva del Garda, Italy, 3394-3403.

Priestley, M. J., Sritharan, S. S., Conley, J. R., and Pampanin, S. (1999). "Preliminary results and conclusions from the PRESSS five-story precast concrete test building." PCI Journal, 44(6), 42-67.

Ranta-Maunus, A. (1975). “The viscoelasticity of wood at varying moisture content.” Wood Sci. Technol, 9 (3), 189-205.

Sarti, F., Palermo, A., and Pampanin, S. (2016). "Quasi-static cyclic testing of two-thirds scale unbonded 
post-tensioned rocking dissipative timber walls.” Journal of Structural Engineering, 142(4), 1-14.

Smith, T., Ponzo, F. C., Di Cesare, A., Pampanin, S., Carradine, D., Buchanan, A. H., and Nigro, D. (2014). "Post-tensioned glulam beam-column joints with advanced damping systems: Testing and numerical analysis." Journal of Earthquake Engineering, 18(1), 147-167.

Standards New Zealand (1992). NZS 3404: Steel Structures Standard. Standards New Zealand, Private Bag 2439, Wellington, New Zealand.

Standards New Zealand (1993). NZS 3603: Timber structures standard. Standards New Zealand, Private Bag 2439, Wellington, New Zealand.

Standards New Zealand (2006). NZS 3101: Concrete structures standard. Standards New Zealand, Private Bag 2439, Wellington, New Zealand.

Sullivan, K., Miller, T. H., and Gupta, R. (2018). "Behavior of cross-laminated timber diaphragm connections with self-tapping screws." Engineering Structures, 168, 505-524.

Tannert, T. (2019). "Design provisions for cross-laminated timber structures." Structures Congress 2019, $127-136$.

van de Lindt, J. W., Amini, M. O., Rammer, D., Line, P., Pei, S., and Popovski, M. (2020). "Seismic Performance Factors for Cross-Laminated Timber Shear Wall Systems in the United States.” Journal of Structural Engineering, 146(9), 1-16. 